\title{
Divan Şiirinde Güneşin Sevgili Tipine Yansıması Hakkında Bir Değerlendirme"
}

\author{
An Evaluation Concerning the Reflection of Sun on \\ the Type of Beloved in Divan Poetry
}

Ö Z E T

Osmanl coğrafyasının sosyo-kültürel kimliğini gelene$\breve{g}$ in getirdiği köklü birikimle yansitan Klasik Türk şiirinin ana teması aşk, temel karakterleri ise sevgili ve âşık tipleridir. Divan şairi aşk, sevgili ve âşık üzerine oluşturulan hayal dünyasına şairliğinin gücü nisbetinde katkıda bulunmuş, söyleyişi zenginleştirmiştir. Böylece divan şairi sevgilisini, ona ait ve onun etrafindaki her şeyi güzelliğiyle övïp yüceltirken çevre-eşya-insan malzemesini -dolaylsıyla aşkl-orjinal hayallerle yeniden yorumlamıştır.

$B u$ çalışmada, divan şiirinde insanoğlu için vazgeçilmez bir hayat kaynağı olan güneşin ve güneşle ilgili tasavvurlarm; yine divan şiirinin vazgeçilmez tipi sevgili ve sevgiliyle ilgili unsurlarm bir benzetileni olarak kullanıldığı mecaz dünyası, beyit örnekleriyle yansıtılmaya çalışılmiştır.

A N A H T A R K E L İ M E L E R

Divan şiiri, sevgili, güneş.
A B S T R A C T

Main theme of Classical Turkish poetry, that reflects the socio-cultural identity of Ottoman geography with the experience rooted in tradition, is love and its main characters are the types of lover and beloved. Divan poet has contributed to the world of imagination based on love, beloved and lover in proportion to power of his poetry and enriched this genre. Thus Divan poet, while praising and glorifying the beloved and everything around her, reinterprets the material of environment-object-human thereby love - with original images.

In this study, metaphorical world in which the sun, an essential source of life for human being, and representations about it are used as a resemblance of beloved which is also an essential type in Divan poetry and the elements about her is tried to be reflected with the examples of verse.

$$
\text { K E Y W O R D S }
$$

Divan poetry, beloved, sun.

*Dr. (umran.ay@gmail.com)

${ }^{* *}$ Beyitlerin künyelerinin gösterilmesinde şu yöntem kullanılmıştır:

Şairin adı, şiirin divandaki numarası/beyit numarası (eseri yayına hazırlayanın adı, şiirin yayında bulunduğu sayfa numarası.) Örnek: Hayretî, G.349/4 (Çavuşoğlu, 350); Pervâne Beğ Mecmuâsı'ndan (PB) alınan beyitlerde ise; Şairin adı/zemin gazelin numarası-nazire gazelin numarası (Pervane Beg-gazelin bulunduğu varak numaras1) Örnek: Münîrî/43-5 (PB-63b) şeklinde belirtilmiştir. Makalenin hacminin kabarmaması için metin içinde sadece teması aktarılan beyitlere (Nedim,G.142/2) şeklinde künye olarak işaret edilmiştir.

Beyit künyelerinde kullanılan kısaltmalar ise şunlardır: G (Gazel), K (Kaside), MG (Musammat Gazel), MH(Muhammes), TG (Tahmis Gazel), Ş (Şarkı), TB (Terkib-i Bend), HŞ (Hüsrev ü Şîrîn), ŞEH (Şehrengiz). 


\section{Giriş}

Şair ve yazarlar vücuda getirdikleri eserlerle yaşadıkları döneme ayna tutarken, sonraki nesillerin de hafızası olurlar. Klasik Türk şiirinde de şairler beş duyuyla algıladığı her şeyi, yaşadığı çağın insan, mekân ve zaman tasavvuru, fiziki ve sosyal çevre, dinî hayat, tarihî hadiseler, tababet vb. alanlardaki gözlem ve birikimini mecazlar dünyasında belâgât ve ahenk unsurlarıyla besleyerek sayısız eser kaleme almışlardır. Divan şairinin tabiat ve fizikî çevreye dair gözlemlerinde gökyüzü ve gökyüzüyle ilgili kozmik unsurlar önemli bir yer tutmuş gerek müstakil eserlerde gerekse bu eserlerin bir bölümünde işlenmiştir. ${ }^{1}$ Mitolojide ${ }^{2}$, Türk destan geleneğinde ${ }^{3}$ ve sözlü kültürümüzde ${ }^{4}$ çeşitli anlamlar yüklenen

1 “Göklerle ilgili unsurlar, özellikle şamanist dönemde Türklerin kültüründe mühim rol oynamış ve buna bağlı olarak günümüze kadar gelen çeşitli tasavvurlar doğmuştur. İslâmî devrede de göklerle alakasını devam ettiren Türkler, bu konuyla ilgili olarak hem edebî hem de ilmî birçok eser vücuda getirmişlerdir. Bunlardan edebî eserlerin en güzel numuneleri olarak Nizâmî'nin Heft Peyker, Ali Şir Nevâî́nin Seb'a-i Seyyâre, Fuzûlî'nin Heft Câm adlı eserlerini zikredebiliriz. İlmî eser olarak ise Erzurumlu İbrahim Hakkı'nın Marifetnâme'si çok mühimdir... Ayrıca Mihr ü Mâh ve Mihr ü Müşterî mesnevileri, Miracnâmeler ve Mevlidler göklerin ve gezegenlerin en fazla konu edildiği eserler arasında sayılabilir... Ahmedî́nin İskendernâme adlı eserinin başındaki göklerle ilgili tasvirler de yıldıznâmelere güzel bir örnek teşkil eder." Bu konuyla ilgili ayrıntılı bilgi için bkz. (Deniz 1992: 7-8).

${ }^{2}$ Kozmik düşüncede bilgeliğin, bütünlüğün, gizemin simgesi olan güneş kültünün oluşmasında güneşin koruyuculuğu, canlılara hayat vermesi, ışığın ve sicaklığın kaynağı olması bilgisi vardır. Yakın Doğu mitolojilerinde yağmur, fırtına, şimşek, gök gürültüsü ve güneş tanrıları kartalla simgelenirdi. Yunan mitolojisinde de kartal, güneş tanrısı Apollo'yu ve fırtına-şimşek tanrısı Zeus'u simgeler. İslam mitolojisinde de güneş, ihtiyar kartal olarak batıdaki karanlık sulara daldıktan sonra gökyüzünün doğu tarafında yeniden gençleşir ve gece boyunca karanlık sularında yürüdüğü okyanusa karşı bir zafer kazanmış olarak yeniden dünyaya geri gelir (Tekin 2004: 85-111) ${ }^{2}$. İslam mitolojisinde güneşin sembolü olarak kartalla (Nesr/ Ukab) çok yakından ilgili bir diğer kuş da Ankâ (Sîmurg)dır. Kartalla onun arasındaki fark kartalın güneş karakteristiklerine sahip gerçek bir kuş olmasına rağmen, Ankâ'nın güneşi simgeleyen efsânevî bir varlık olmasıdır (Tekin 2006: 209).

3 Türk coğrafyasında kültürün başlıca taşıyıcısı geleneklerden destanlara güneşle ilgili olarak; güneşi şahit tutarak yemin etme, bahar ve sonbahar ekinokslarında yapılan güneş ve ay ayinleri, Hun hükümdarlarının güneşe karşı üç kez diz çökerek güneşi selamlaması, çadırların kapısının doğuya, güneşin doğduğu yöne açılması (Bayat 2007: 297-303), güneşe karşı ant içme, güneşe karşı saç tarama, güneşe ok atma, güneşin batmadığı ayın çıkmadığı yerlerin varlığı, sekiz güneşe selam, hükümdar sikkeleri, mezar taşları ve ayin elbiselerine, mektuplara güneş ve ay motiflerinin işlenmesi gibi inançlar ve uygulamalar mevcuttu (Ögel 1995: 187-195). 
güneş; tek olması, büyüklügüu, bütün kâinata 1sısı ve 1şığıyla hayat vermesi, göz alıcı parlaklığı, doğudan batıya devri ile divan şairinin de gökyüzüne ait unsurlar içinde en çok dikkatini çeken cisimdir (İz 1999: 127). Divan şiirine değişik müşahade, telakki ve inanışlarla giren güneş üzerine yapılan teşbih ve mecazların sayısı oldukça fazladır. ${ }^{5}$ Divan tahlili çalışmalarında güneşle ilgili unsurlara bir hayli yer verilmesi bize bu konuda bir fikir verir (Çavuşoğlu 1971, Sefercioğlu 1990, Kurnaz 1996b). Güneş; eski astronomi bilgisine göre 4 . kat gökte oluşu' ${ }^{6}$, doğudan batıya seyri, bu seyir esnasında doğuşu ve batışı, devri sırasında aldığı renk ve görünümler, ışınları, sıcaklığı, kâinata ve bütün canlılara hayat vermesi, gökyüzündeki yeri, ay, yıldızlar, burçlar ve diğer gezegenlerle münasebeti, bitki ve madenler üzerindeki tesiri, bulutlarla değişen görüntüsü vb... yönleriyle çeşitli açılardan divan şairine zengin bir ilham kaynağ olmuştur. Ayrıca dinî ve tasavvufî olarak yüklendiği anlamlar da şiirde yer almıştır. Sadece güneş, şems, âfitâb, mihr, hurşid redifleriyle yazılmış kaside ve gazellerin bile tamamını henüz görmemiş olmamıza ră̆men bugüne kadar yaptığımız okumalardan güneşle ilgili yapılan teşbih ve mecazların tahminimizin çok üstünde olduğu kanaatine vardık. Divan şiirinde daha ziyade sevgili ve padişah olmak üzere pek çok varlığın kendine mahsus özellikleri ile güneş arasında benzetmeler yapılmıştır. Allah; Hz. Muhammed, Hz. Yusuf, Hz. İsa, Hz. Musa, Hz. Süleyman

\footnotetext{
${ }^{4}$ Başına gün doğmak, gün gibi âşikâr, gün görmek, gün yanığı, gün yüzlü, güneş olsa 1şık saçmaz, güneş gibi doğmak, günlük güneşlik, güneş balçıkla sıvanmaz, güneş girmeyen eve doktor girer...Bu meyandaki deyim ve atasözleri güneşle ilgili inanışları sözlü kültür malzemesi olarak yüzyıllardır yaşatmaktadır (Eyüpoğlu 1975).

${ }^{5}$ Bu konuyla ilgili şu çalışmalara bakılabilir: Sabahat Güler, Fuzûlî Divanında Kozmik Unsurlar, Basılmamış Yüksek Lisans Tezi, Marmara Üniversitesi Türkiyat Araştırmaları Enstitüsü, İstanbul 1986; Sebahat Deniz, 16.yy. Bazı Divan Şairlerinin Türkçe Divanlarında Kozmik Unsurlar, Basılmamış Doktora Tezi, Marmara Üniversitesi Türkiyat Araştırmaları Enstitüsü, İstanbul 1992; Cemal Kurnaz, Taşlıcalı Yahya Bey Divanında Kozmik Unsurlar, Basılmamış Yüksek Lisans Tezi, Gazi Üniversitesi Sosyal Bilimler Enstitüsü, Ankara 1981.

${ }^{6}$ Güneş, dördüncü kat gökte olup tabiatı itidâl üzre sıcak ve kurudur. Erkek olup gündüze nisbet edilmiştir. Sa'd-ı evsat diye de isimlendirilmiştir. Vasıfları kuvvet, şiddet, kahr, zor yatışan öfke, rağbet, his, rikkat, hayâ ve iffet bulunmuştur. Pazar günü ve Perşembe gecesine hâkim bulunmuştur (Erzurumlu İbrahim Hakkı 1983: 118-119).
} 
gibi peygamberler; Cemşid, İskender, Nuşinrevan, Züleyha gibi mitolojik şahıslar; adalet, cömertlik, şöhret-i âfâk, sultân-1 hâver, alem, tâc, taht, sorguç, mühür, tuğra gibi padişahlıkla ilgili unsurlar; otağ, okçu, nişangâh, kılıç, miğfer, kalkan, davul gibi savaşla ilgili unsurlar; sevgilinin güzellik unsurları, âşığın güneş gibi olan sevgili karşısındaki hâlleri; altın divit, kevser, mey, mizber, mıstar, çadır ipi, gül bahçesi gibi ışınlarıyla ilgili unsurlar; içkiyle ilgili unsurlar; abdâl, mürşid, derviş, rind gibi tasavvufî tipler; gavvâs, fişekçi, gelin süsleyici, fassâd, müşteri, misafir, süt veren anne, ezber yapan talebe, defçi, çâker, köle, âyinedâr, ateşbâz gibi diğer tipler; inci küpe, yüzük, çadır deseni, elbise motifi gibi süs unsurları; darı, buğday, ekmek, süt, kadayıf gibi yiyecekler ve içecekler; gül, şebnem, yaprak gibi bitkiler ve toprakla ilgili unsurlar; ayna, düğme, testi, usturlâb, para, yastık, çömlek gibi eşyalarla ilgili unsurlar; tâvus, pervâne, şahbâz, horoz, aslan, güvercin gibi hayvanlarla ilgili unsurlar; duhâ (kuşluk vakti), işrak namazı, bayram namazı gibi vakitle ilgili unsurlar... şeklinde güneşle ilgili teşbihler listesini uzatmak mümkündür. Güneşle ilgili kaydettiğimiz teşbihler listesinin bir tablo hâlinde derlenmesi devam etmektedir, güneş mecazlarının zenginliği bize, bu mevzuun bir makalenin sınırlarını aştığını göstermiştir. Beyitlerde çok sıkça karşılaştığımız güneş-sevgili, münasebetinden yola çıkarak çalışmamızda öncelikle bu konunun ele alınması düşünülmüştür. Tesbitine devam ettiğimiz diğer mecazlar zaman içinde yeni çalışmalarımıza konu olacaktır.

Divan şairi zengin hayal dünyasına parelel olarak güneşi çeşitli isim ve sıfatlarla şiirine konu eder. Gün, âfitâb, şems, hûr, hûrşîd, mihr gibi isimleri olan güneş, yukarıda saymaya çalıştığımız değişik hâl, görünüm ve renklerine yapılan teşbihlerin yanı sıra parlaklığı ve gökyüzünün süsü olması bakımından tâbnâk, tâbân, tâbende, âlem-sûz, rahşân, dırahşân, pür-nûr, münîr, münevvir, şuledâr, ziyâ-güster, ziyâ-efrûz, pür-envâr, nûr-efşân, âlem-ârâ, âlem-efrûz, âlem-tâb, cihân-ârâ, cihânefrûz, felek-ârâ, zerrîn..gibi sıfatlarla da anılır (Küçük 1988: 150).

Divan şiirinde sevgilinin kendisi veya güzelliğinin bir parçası, süsgiyim kuşam unsurları, kullandığı eşyalar ve sevgilinin çeşitli hâlleriyle tasvirlerine konu olan güneş; kimi zaman da divâne, ayinedâr, köle, kararsız âşık gibi sıfatlarla karşımıza çıkar. Sevgili ve âşık tipinin dışında sevgilinin güzelliğine imrenip ona benzemeye çalışan, sevgiliyi 
kıskanan, sevgilinin güzelliğiyle boy ölçüşemeyecek derecede bu güzelllik ve parlaklık karşısında sönük kalan bir varlığı temsil ettiği de olur. Güneşin benzeyen ya da benzetilen olarak tasvir edildiği sevgili tipini ve benze(t)me yönleri makalenin bundan sonraki bölümlerinde alt başlıklarla incelenecektir.

\section{A. Güneş-sevgilinin kendisi}

Divan şiirinde sevgiliyle ilgili tasavvurlar oldukça zengindir. Billur sinesi, altın sarısı ya da gece karası saçları, zülfü, parlayan alnı, melek gibi nurlu yüzü ile baştan ayağa nur parçasını andıran güzelliğinin yanı sıra tavır ve edâsıyla âşı̆̆ın gönlünü çalan bir güzel şairin hayal dünyasında çeşitli benzetmelere konu olur. Yusuf, İsa, Süleyman, Hızır, perî, melek, hurî, şem, hakan, hüsrev, padişah, cân, tabîb, gonca, gül, fidan, serv, ay, güneş, yıldız, tıfl, dürr, güher, câdû, âhû, gazal, hümâ, bahar, sabah, su, sanem, kafir (Sefercioğlu 1990: 122-138) onlardan bazılarıdır. Bunlar arasında makalemize konu olan güneş benzetmesi en yaygın olanlarından biridir. Eşsiz güzelliği, tek olması, âşığın gönlünde yüce bir makamda bulunması, âşığa hayat vermesi, ulaşılmazlığı, bulunduğu yeri aydınlatması, şöhretinin bütün âleme yayılması, yüzünün parlaklığı, gelişiyle gönüllerin aydınlanması, gidişiyle âşı̆̆ın dünyasının kararması, göz kamaştırıcı güzelliğinin yanında başka güzelliklerin sönük kalması gibi özellikleriyle divan şairinin ana karakteri olan sevgili ile güneşle pek çok benzerlik arzeder. Güneşin doğuşu sevgilinin güzelliğini arz etmesi (Revânî, G.152/1), âşığın hanesine gelmesidir.

O, güzellik göğünün parlak bir güneşi (Hayretî,G.262/2), yakıc1 güzelliğiyle bir mahşer güneşidir (Açıl 2008: 129).

Ol kâmet üzre ol hurşîd sûret

Kıyâmet güni gibi pür-harâret

Mesîhî, ŞEH.157 (Mengi, 106)

O mahşer güneşine bakmaya âşığın ne tâkâti ne de kudreti vardır.

Kiyâmet günine benzer o meh-rûda mehâbet var

Temâşâ-yı cemâline ne tâkât var ne kudret var

Taşlıcalı Yahya, G.60/1 (Çavuşoğlu, 318) 
Âşığın gözünde ulaşılmaz bir varlık olan sevgili güzelliğiyle göz kamaştırır (Nedim,G.142/2). Güneşe bakıldığında nasıl gözler kamaşırsa ${ }^{7}$ güzellik gögünün parlak güneşi olan sevgilinin güzelliğine de çılak gözle bakılamaz, ancak ayna tutularak bu güzelliğin aksi görülür (Çâkerî, G.103/1). Güneşin cihanı aydınlatması gibi o da âşığın karanlık gönlünü ziyasıyla nurlandırır, güneşin kâinata hayat vermesi gibi o da âşığa yaşam kaynağı olur. Güzelsiz âşığın gözüne âlem karanlık görünür (Revânî, G.148/4). Gümüş renkli billur sinesiyle sevgili âdeta baştan ayağa bir nur hâlesi gibidir.

Ol büt-i sîmîni gördüm sînesi billûr imiş

Gün gibi başdan ayaga bir musavver nûr imiş Üsküblü İshak Çelebi, G.114/1 (Çavuşoğlu, 191)

Güneşin doğuşu, sevgilinin hanesini ziyaret etmesidir.

Subh-dem yaturken ol meh üstüme geldi didi Üstüne gelmiş güneş sen dahı uyanmaz mısın

Karamanlı Nizâmî, G.83/3 (İpekten, 203)

Sevgiliden ayrı geçen her gün âşığa karanlık bir gecedir.

Göz göre sensüz şeb-i târ oldı rûz-1 rûşenüm Kandasin ey âfitâb-1 âlem-ârâ kandasın

Hayretî, G.349/4(Çavuşoğlu,350)

"Güneş girmeyen eve doktor girer." atasözü güneşin insan sağllğ 1 için önemini vurgularken evin yönünün güneşe doğru olması, odalar1nın güneş görmesi gerektiğine de dikkat çeker. Yahya Bey de bundan hareketle güneş gibi dünyasını aydınlatan, gözlerine fer veren sevgilisine şöyle seslenir:

Açllur senden yana her gün gözüm nergisleri

Âfitâbum hânenün câmı güne karşu gerek

Taşlıcalı Yahya, G.225/4 (Çavuşoğlu, 424)

\footnotetext{
${ }^{7}$ Güneşin gözleri kamaştırması, güneşe bakılamamasıyla ilgili bir halk inanışı şöyledir: "Güneş çok güzel bir kızmış. Bütün gözler ona çevrildiği için bir türlü yeryüzüne çıkmak, insanlara görünmek istemezmiş. Erkekler ona baktıkça utanırmış. Annesi bakmış ki bu iş yürümeyecek, düşünmüş taşınmış. Güneşe birçok iğne vermiş. Dünyaya çıktığında kim senin yüzüne bakarsa bu iğneleri onun yüzüne batır, demiş. İşte insan güneşe bakınca gözlerinin kamaşması bundanmış." (Eyüboğlu 1987: 71).
} 
Karanlık mekânlarda dar bir alandan güneş ışığı içeriye yansıd1ğında ışığın sızdığı açı boyunca toz zerrecikleri hareket halinde görünür. Aynı zamanda zerreciklerin görünmesi ışığın olmasına bağlıdır, yani zerrelerin varlığını gösteren şey de ışıktır. Toz zerreciklerinin ışık etrafındaki hareketi tasavvuf terminolojisindeki pervane sembolünü yahut semâ'ı hatırlatır. Mumun etrafındaki pervane ${ }^{8}$ veya ilâhî aşkın neşvesiyle rakseden semâzen' gibi divan şiirinde kendilerini zerre addeden âşıklar da güneş sevgilinin pervaneleri, zerreleridir. Onun varlığı sevinç, mutluluk vesilesidir çünkü; âşığın varlığı ancak aşkına muhatab olan sevgilinin varlığıyla mümkündür. Aşağıdaki beyiti aşkın her iki ciheti için de değerlendirmek mümkündür.

Ârâm idemez dil göricek sâgarı pür-mey

Hurşîdi göricek nola raks eylese zerrât

Hayâlî, G.31/3(Tarlan,99)

\section{Farklı elbiseleriyle sevgili}

Güneşin yansıttı̆̆1 1şıklarla gökyüzü günün değişik saatlerinde farklı renklere bürünür. Bu gözlemden hareketle sabah, öğlen ve gurûb vaktinde gökyüzünün aldığı renkler sevgilinin giyindiği elbisenin rengi,

${ }^{8}$ Hallâc, Kitâbu't-Tavâsîn'in "İdrâkin Tâsînî" bölümünde pervane sembolüne yer verirken bu mecazı sadece mistik boyutlarıyla yorumlamakla kalmaz, aynı zamanda vecdin psikolojisini izah eder, "aşk estetiği"ni temellendirir.(Pervane sabahlara kadar / mum ışı̆̆ının etrafında uçar / sonra dönüp gelir hemcinslerine / anlatır onlara mutluluğunu latif sözlerle / sonra özenerek ermek için kemale / nice cilveli güzelliklerle birleşir / ... / ne ışığı temaşaya doydu pervâne / ne sıcağıyla yetindi divâne / attı kendini tümden alevlere / hemcinsleri yolunu beklemede / ki nakletsin gördüklerini bakışıyla / lakin o yetinmedi sadece malumatla / uçtu, döndü, yaktı kendini, yok oldu ortadan / resim, cisim, iz, işaret kalmadı geriye ondan / o artık niçin geri dönsün ki şekillere! / vuslattan sonra hangi hâl var ki döne.) (Özkan 2006: 67).

${ }^{9}$ Mevlânâ ise Fîhi mâ fih'te pervâne mecazını tüm yaratılanlara teşmil eder. Ona göre bütün yaratıklar daha üstün bir hakikatin etrafında pervanedirler. Tüm varlıklar Goethe'nin tabiriyle "Ve daha ulvî bir izdivaç için / Yeni bir istekle kanatlanır(lar)." Dünya, ay, seyyareler ve tüm yıldızlar bu ulvî hakikatin pervanesi kesilir ve döne döne varlıklarını eritirler. Mevlânâya göre zerreden aya, yıldızlara ve seyyarelere kadar tüm varlıklar ebedî aşkın "pervâneleri"dir. Semâ' onların ebedi varoluş ve yokoluş maceralarının manifestosudur (Özkan 2006: 79). 
güneş de onları giyinmiş sevgili gibi tahayyül edilir. Şairlerimiz güneşi; parlak, süslü elbiselerle göz kamaştıran sevgiliye benzetirken bu vesileyle zamanlarında makbul olan elbiseleri de zikretmiş olurlar. Âsumânî̀ ${ }^{10}$, serâser ${ }^{11}$, kabâ $^{12}$ gibi kumaşlar bunlardan bazılarıdır. Şafak vaktinde güneş, kırmızı duvaklı geline; öğlen saatlerinde altın sarısı 1şıklarıyla, sırmalarla işli elbise giymiş bir güzele, bulutsuz mavi bir gökyüzünün ortasındaki haliyle, mavi elbise giymiş sevgiliye, gurûb vaktinde ise kırmızı elbiseli dilbere teşbih olunur. Bu tasvirleri beyit örnekleriyle inceleyelim.

Sabah tasvirlerinde gökyüzünün aydınlanması çok defa geline benzetilen güneşin duvağını kaldırması yahut bir güzel olarak tasavvur edilen güneşin yüzünden yaşmağını açması şeklinde yorumlanmıştır (Şentürk 1995: 4).

Şafak vaktinde tan yerinin önce kızarıp sonra ağarmasını gözlemleyen şair, doğan güneşi istiare yoluyla "âlem gelini" diye tavsif eder. Bu gelin ellerini boyamış, başına al bir duvak bürümüş, altın bir taç giymiş, mavi bir tahta -yani gökyüzüne-oturmuştur (Şentürk 2002: 139).

Meger bir subh kim 'âlem gelini

Boyar yüz reng ü âl ile elini

Bürür gerçi başına al tuvag1

Kılur nûrânî anı yüzi agı

Arûs-i çarh pîrûze eyleyüp baht

Urinur tâc-1 zer pîrûze-gûn taht

Şeyhî, HŞ.6386-6388 (Timurtaş,242)

\footnotetext{
${ }^{10}$ Âsumânî: Mavi renkli bir çeşit kumaştan yapılan elbisenin adı (Onay 2007: 134).

${ }^{11}$ Serâser: İpekli ve baştan başa her tarafı altın ve gümüş tellerle işlenmiş eski ve çok kıymetli bir kumaşın adıdır ki ekseriya serâserin altın ve gümüş telleri arasına inciler de katılmış olurdu (Koçu 1969: 204).

${ }^{12}$ Kabâ: Meydânî denilen al beyaz çizgili bir ipekli dokumadan yapılan, yan etekleri çift yırtmaçlı, göğüs kısmı açı ve yakası topuğa kadar kesik ve bütün yakası sırma ve ipek gaytanla işlenmiş entâri (Onay 2007: 211).
} 
Dünyanın ve sevgilinin ortak vasıflarından biri vefasız olmalarıdır. Dünya içindeki türlü nimetlerle, güzelliklerle insanoğlu için yalancı bir cazibe merkezidir. Çeşitli ziynetlerle süslenen sevgili de âşı̆̆ın gönlünü çalar, onu kendine esir eder. Aşağıdaki beyitte masmavi gökyüzünün ortasında 1şıl ışıl duran güneş mavi elbiseler giyinmiş, göz alıcı güzelliğiyle âşı̆̆ın gönlünü çalan bir sevgili gibi tahayyül edilir. Şair "bî-vefâ" kelimesiyle hem sevgiliyi hem de dünyanın vefasızlığını anlatarak sihr-i helâl $1^{13}$ sanatı yapmıştır.

Zînet itmiş kendüyi ol bî-vefâ dünyâ gibi

Âsumânîler geyer mihr-i cihân-ârâ gibi

Üsküplü İshak Çelebi, G.303/1 (Çavuşoğlu,316)

Eskiden hükümdarlar kırmızı veya kırmızıya yakın renkli elbise giyerlermiş. Şairlerimiz sevgililerini birer hükümdar gibi tahayyül ettikleri için onları kırmızı ve turunç renkli elbise ile gördükçe memnuniyet duymuşlardır (Onay 2007: 133).

Güneşin 1şıklarıyla ortalığı yakması gibi sevgili de ne zaman altınlı kabasını giyse 1şıltılı sarı elbisesiyle âşıkların canlarını dağlar (Revân̂, G.298/1).

Şafak vakti doğarken baştanbaşa gökyüzünü kızıla boyayan güneş kırmızı elbiseler giyinmiş âşıkların gönlünü yakan bir güzeller şahı sevgilidir $^{14}$. Sevgilisine mihr-i cihân diye seslenen Ulvî, aşağıdaki beyitte "serâser" kelimesiyle tevriye yaparken sevgilinin hem kırmızı serâser elbisesine hem de bütün dünyayı baştan başa yakıp kavuran güzelliğine işaret ediyor.

Serâser âlemi yakdın nola lâlîn kabâlarla

Şafakdan arz-1 ruhsâr eylemiş mihr-i cihânsın sen

Ulvî, G.18/3(Tarlan, 25)

\footnotetext{
${ }^{13}$ Sihr-i helâl, beyit arasında hem kendisinden önceki sözlerin sonu hem de kendisinden sonraki sözlerin başı olabilecek şekilde söz söylemektir. Bu söz bir kelime olabileceği gibi birden fazla kelime de olabilir. (Saraç 2006: 297)

${ }^{14}$ Kabâ-yı sürh ile olmuş pür âteş mihr-i rahşânım

Bahâneyle cihânı yakmak ister şâh-ı hûbânım Nedîm-i Kadîm (Onay 2007: 211)
} 


\section{B. Güneş-sevgilinin uzuvları, güzellik unsurları:}

\section{Sevgilinin yüzü:}

Sözlü kültür varlığımız olan deyimlerimiz arasında geçen "nur yüzlü, yüzünden nur akmak" gibi ifadeler yüz aydınlığının, temizliğin, insanın iç güzelliğinin bir yansıması olduğunu belirtir. Sevgilinin yüzünün güzelliği bütün kâinatı nurlandıran, aydınlatan bir ışık gibidir, 1ş1ğıyla âleme aydınlık veren güneş yüzlü sevgilide Allah'ın nuru tecelli etmiştir.

\section{Şem'-i rûyun âftâb-ı âlem-ârâdur senün \\ Nûr-ı Hak hurşîd-i ruhsârunda peydâdur senün}

Fuzûlî,G.170/1 (Akyüz,212)

Sevgiliyi gören kişi yüzüne gün doğmuş, gözü aydın olmuş, güngörmüş sayılır. Âşık her zaman sevgilinin yüzünün açık olmasını istemez; bazen de zülfünü yüzünden kaldırmamasını arzu eder. Çünkü güneş ne kadar çok açılırsa sıcağı da o derece artar ve insanı yakar. Esas itibariyle güzellik sembolü olan güneş yüksekliği yönünden de sevgili ve övülenin benzetileni olmuştur, "başı göğe ermek" deyimiyle buna işaret edilir (Kurnaz 1996a: 294-295). Yüz, yuvarlaklığı, parlaklığı ve yakıcılığı bakımından güneş gibi hayal edilir. Bunun dışında yüzle ilgili divan şiirinde ay (mâh, meh, mehtâb), gül, gülşen, ateş, şem, çerağ, ayna, deniz, akarsu, Kâbe, mushaf, ayet, kitap, defter, varak, cennet, bayram, devlet, hazine, Misr gibi benzetmeler de mevcuttur.

Yüzün güneşe teşbihinde, güneşin parlaklığı, rengi ve yakıcılığı esastır. Onun yüzü o kadar parlak ve nurludur ki âşı̆̆ın gözlerini kamaştırır ve yaşartır.

Bakamaz kimse güneş yüzine gözler kamaşur

Görenün aklı gide özge temâşâdur bu

Çâkerî, MG.3/4 (Aynur,80)

Gün yüzin hem gösterür hem dir göze nem gelmesün

Çeşme-i çeşme nice eşk-i dem-â-dem gelmesün

Bâkî, G.355/1 (Küçük,319)

Şafak vaktinde doğan güneş sevgilinin yüzünü göstermesine benzer (Mesîhî, G.286/3). 
Ay ve yıldızların ışığını güneşten alması gibi sevgilinin etrafındaki her varlık da onun yüzünden saçılan ışıkla hayat bulur. Güneş tal'atlu bu yüzü kim aya benzetirse o ancak kara yüzlü bir yalancıdır.

Ol âfitâb-tal'ata kim derse mâh-rû

Olsun cihânda meh gibi dâ'im siyâh-rû

Bâkî, G.401/1 (Küçük,347)

Güneş görününce yıldızların kaybolması, yağmurun dinmesi gibi sevgili yüzünü gösterince de âşığın yıldız ve yağmura benzeyen gözyaşları görünmez olur.

Eşk-i çeşmüm mahv olur gördükçe yârun sûretin

Tagıdur hurşîd çünkim encümün cem'iyyetin

Mesîhî, G.188/1 (Mengi, 238)

Yukarıdaki durumun tersine şiddetli yağmur yağdığında da güneş kaybolur. Âşığın gözyaşlarını sağanak yağmura benzeten Karamanlı Nizâmî, gözyaşlarının güneş yüzlü sevgilinin görünmesine engel olacak kadar şiddetli aktığını şöyle belirtir.

Yüzüni görmese n'ola çeşmüm giryân olıcak

Âfitâbı göremez kimsene bârân olıcak

Karamanlı Nizâmî, G.56/1 (İpekten, 176)

Sevgilinin yüzünden örtüsünü kaldırması bulutların arkasından güneşin çıkması gibidir.

Ol kamer-tal'at yüzinden açdı çün müşgîn nikâb

Sanasın kim ebr içinden zâhir oldı âfitâb

Revânî, G.23/1 (Avşar,107)

Sevgilinin güzellik unsurlarından birisi olan zülüf de siyahlığ sebebiyle geceye ve buluta teşbih edilir. Yüzün üstüne düşen zülf güneşin bulutlarla kapanmasinı hatırlatır.

Zülfi kim gül yüzine sünbül-i ter kıldı nikâb

Âfitâbun sanasın kim yüzüni tutdı sehâb

Münîrî/43-5 (PB-63)

Aşağıdaki beyitte zülüf-nakkâş (müzehhib), saç-kıl kalem, yüzşemse deseni hayaliyle kurulan benzetmelerde aynı zamanda tezhip sanatının şemse, kıl kalem, tahrir çekmek gibi terimleri de ustaca yerini almiştır. 
Gün şemsesinün dâiresün eyledi tahrîr

Nakkâş mıdur zülfi k'anun kıl kalemi var

Revânî,G.63/4 (Avşar,122)

Bâkî́nin aşağıdaki beytinde güneş yüzlü sevgiliden ayrılan âşık intihar eder. Zira felek de bir güneş yüzlü sevgilinin ayrılığından dolayı durmadan ağlayan âşık gibi hançere düşmüştür. Feleğin hançere düşmesi güneşin kaybolması sebebiyle hançer şeklini almış olan ayın göründüğ̈ karanlığa kalmak olarak düşünülmüştür.

Bir güneş yüzlü firâkında felek hasret ile

Var ise hançere düşdi nitekim 'âşık-1 zâr

Bâkî, K.25/4 (Küçük,66)

Sevgilinin çıra gibi yanan, ay gibi bembeyaz olan yüzü kimi zaman parlaklığıyla güneşi bile gölgede bırakır. En parlak güneş olan kuşluk(duhâ) güneşi ${ }^{15}$ bile bu güzelliğin yanında sönük kalır (Onan 1991: 36). Kuşluk vakti Kur'ân-1 Kerim'de adı geçen kıymetli vakitlerden biridir. Hz. Peygamber'in kuşluk vaktinde nafile namaz kıldığı ve ashabına da tavsiye ettiği pek çok hadiste geçmektedir.

Yârab ne şem imiş bu mehün yüzi kim anun

Yüzi katında şems-i duhânun ziyâsı yok

Nesîmî, G.33/6 (Ayan, 97)

Âşıklar için sevgilinin yüzünü görebilmek oldukça zordur. Âşık içindeki aşk hasreti ve kavuşma arzusuyla bu anı bekler. Sevgilinin yüzünü gördüğü vakit ise âdetâ bayram sevinci yaşar. Bayram, milletlere ait toplu sevinç, mutluluk ve ortak kutlama vesilesi olarak kabul edilen belirli zamanlar için kullanılan bir terimdir. İslâm dininde Ramazan ve Kurban Bayramı olmak üzere iki bayram bulunmaktadır. Her iki bay-

\footnotetext{
${ }^{15}$ Güneşin doğduktan sonra 50 (bir mızrak boyu) yükselmesinden, başka bir deyişle güneşin doğmasından takriben 45-50 dakika geçmesinden, zeval vaktine kadar olan süreye kuşluk (duhâ) vakti; bu zaman diliminde kılınan nafile namaza da duhâ namazı denir. Diğer bir ismi de kuşluk namazıdır. Kur'ân-1 Kerim'de 93. surenin de adıdır. "Ve'd-duhâ" âyetiyle başlayan bu surede Cenâb-ı Allah'ın kullarına verdiği nimetler hatırlatılarak şükretmesi, yetimleri ezmemesi ve isteyeni azarlamaması hatırlatılmaktadır. http://www.diyanet.gov.tr/turkish/dy/Diyanet-IsleriBaskanligi-AnaMenu-dini-kavramlar-sozlugu-92.aspx (10.03.2009)
} 
ramda da güneş doğduktan sonra bayram namazı kılınır ve "bayramlaşma" başlar. ${ }^{16}$ Yılda iki defa kutlanan ve "Dini bayramlar" ortak adı verilen bu bayram günleri özellikle akraba ve dostların birbirlerini hatırlaması, ziyaret etmesi için birer vesiledir, yani kavuşma günleridir.

Aşağıdaki beyitte "vuslat-bayram", “yüz-âfitâb" kelimeleriyle leff ü neşr sanatı yapan şair nasıl ki güneş doğduktan sonra bayram namazı kılınırsa bana da senin güneş yüzünü görmek bayram gibidir, bu sebeple ben de yüzünü görüp -şükür için- secdeye varırım diyerek bayram namazının vaktini, aynı zamanda bayramın bir kavuşma günü olduğunu bize hatırlatmaktadır.

Vuslat güninde secdeye vardum yüzün görüp

Bayrâm namâzı çün kılınur togsa âfitâb

Amrî, G.6/3 (Çavuşoğlu,42)

Sevgilinin güneş yüzünün âşıklar tarafından çok ender de olsa görülebildiği durumlarda; mutluluğa, saadete ermek, talihi dönmek, yüzü gülmek anlamlarında başına gün doğmak deyimi kullanılır ( Zâti, G.72/2).

Ol gün togar mı başa ki subh-1 visâl irüp

Hüsnün ziyâsı zulmet-i hicrânı dûr ide

Bâkî, G.420/2 (Küçük,360)

Gün doğar meclis-i uşşâka şeb-i hayretde

Her ne saat ki o hurşîd-i sabâhat uyanır

Şeyh Gâlib, G.73/3 (Kalkışım,291)

Sabah bitkiler üzerindeki çiğ taneleri güneş doğduğunda buharlaşarak kaybolurlar. Bu tabiat olayından gözlemle şair gözyaşı damlalarını rengi ve şekli yönünden çiğ tanesine benzetir. Sevgiliden ayrı kaldığ1 için ağlayan şairin gözyaşlarını ancak onun güneş gibi yüzünü görmek kurutacaktır.

\footnotetext{
${ }^{16}$ Ramazan Bayramı; Ramazan ayının sonunda, Şevval ayının birinci, ikinci ve üçüncü günlerinde kutlanır. Kurban Bayramı ise, Zilhicce ayının on, on bir, on iki ve on üçüncü günleridir. Bu bayramın ilk üç gününde, zengin olan Müslümanların kurban kesmeleri vacip olduğundan Kurban Bayramı denilmiştir. Bayram namazınin vakti, kuşluk vaktidir. http://www.diyanet.gov.tr/turkish/dy/Diyanet-IsleriBaskanligi-AnaMenu-dini-kavramlar-sozlugu-92.aspx (10.03.2009)
} 
Yerde kalmaz gözümüz yaşı bizim şebnem-vâr

Şevk-i dîdârın ile vâsıl-ı hurşîd ederiz

Bosnalı Sabit G.148/3 (Karacan,424)

Divan şiirinde çeşitli vesilelerle sevgilinin yüzünün görünmemesi güneş tutulmasına benzetilmiştir. Bilindiği gibi ayın güneşle dünya arasına girerek güneşin 1şığını kapatmasına küsûf (güneş tutulması) ${ }^{17}$ ay tutulmasına da husûf denir. Halk arasında güneş ve ay tutulması uğursuz sayılırdı. ${ }^{18}$ Güneşi ve ayı kötü ruhların sardığına inanılırdı. Davul, teneke çalma, silah sıkma, diz çökerek dua etme, kurban adama gibi inanışlarda bu uğursuzluktan bir an önce kurtulmak düşüncesi vardır (Şahhüseyinoğlu 2000: 16). Tutulmuş güneşe bakmak da uğurlu sayılmaz; göze zarar vereceğine, bakanın akibetinin iyi olmayacağına inanılır; bakmak isteyenler de renkli çıra isiyle karartılmış bir cam ardından bakarlard1.

Kimi zaman da sevgilinin yüzü güneşten daha güzel olduğu için güneş ya utancından ya da kıskancından tutulur. Hüsn-i ta'lil sanatının

${ }^{17}$ Küsûf kelimesi Arapça'da güneş tutulması anlamına gelmektedir. Küsûf namazı ise, güneş tutulduğunda cemaatle kılınan iki rekatlik bir namazdır. Güneş tutulduğunda namaz kılmak müstehaptır. Hz. Peygamber'in güneş tutulduğunda, mescide giderek namaz kıldığı rivâyet edilmiştir (Müslim, Küsûf, 3-5). Küsûf namazı için ezan okunmaz, kamet getirilmez. Namazı, Cumâ'yı kıldıran imam kıldırır. İmam yoksa, cemaat kendisi ferdî olarak namaz kılar. İmam kıraatı içinden yapar. Hz. Peygamber'in oğlu İbrahim'in öldüğü gün güneş tutulması üzerine, halk İbrahim'in vefatı sebebiyle güneşin tutulduğunu söylemiş; bunun üzerine Rasûlüllah; "Güneş ve ay kimsenin ölümünden veya doğmasından dolayı tutulmaz. Bunu gördüğünüzde namaz kılın, dua edin." buyurmuştur (Buhârî, Küsûf, 1; Müslim, Küsûf, 1,3). Ay tutulması, fırtına, deprem, salgın hastalık gibi korkutucu olaylarda da güneş tutulmasında olduğu gibi namaz kılmak müstehaptır. http://www. diyanet.gov.tr/turkish/dy/Diyanet-Isleri-Baskanligi-AnaMenu-dini-kavramlar-

sozlugu92.aspx (10.03.2009)

18 "Küsûfun mazarratı, mensûbât-1 şemse ve burûcuna sârîdir...Ammâ hüsûfun mazarrâtı mensûbât-ı kamere ve burûcuna sâridir...Eğer müdebbir Zuhal olursa zulme, cevre, kıtlığa, hile ve tezvirâta, ıztırap ve meşakkate ve havanın burûdetine, hastalıklara delildir...Küsûf ve hüsûfun mikdârına göre yani eger küsûf ve hüsûf küllî olsalar, mazarrat ve nüsûsetleri dahi küllî ve kavî olur. Bu hükm üzere her ne kadar az tutulsalar nühûsetleri kalîl olur ve ziyâde tutulsalar mazarrat ve âfetleri kesîr olur." Reisü'l-Müneccimîn Mehmed b. Ali (öl. 1040/1630-1631), İlm-i Nücûm, Süleymâniye Ktp., Kılıç Ali Paşa Bl., nr.694, yk: 37b-39b. (Çelebioğlu 1988: 7-8) 
iki güzel örneği olan aşağıdaki beyitlerin ilkinde Sabâyî, güneşten daha parlak olan sevgilinin yüzünü gören güneşin utancından yüzüne perde gerdiğini bu sebeple görünmediğini belirterek müneccimlerin güneş tutulması var diye yalan söylediklerini belirtir.

Gün tutılur diyü kizb eyler müneccim bilemez

Kim yüzün gördi hayâdan perde tutdı âfitâb

Sabâyî 41-90 (PB-57bh)

Zâtî, güneşin parlaklığını sevgilinin yüzünden çaldığını bu sebeple ceza olarak güneşin tokat yediğini, ellerinin ve ayaklarının karardı̆̆ını görünmez olduğunu belirtir.

Nûr uğurlarken ${ }^{19}$ ruhundan tutdı let urdı küsûf

Kararup a'zâsı çekdi çok belâyı âfitâb

Zâtî, G.63/5 (Tarlan, 63)

Kendisine cefâ çektirmekten başka bir faydası olmayan güneş yüzlü sevgilinin karanlık bir gecede bir maha giriftâr olması için beddua eden Şeyh Gâlib, beddua ile aynı zamanda güneş tutulmasının hatırlattığı kötü duyguları da dile getirmiş olur.

Demem ol şûh-1 cefâ-pîşe bana yâr olsun

Mihr iken zîver-i âgûş̧-1 şeb-i târ olsun

Bed-duâm öyle ki bir mâha giriftâr olsun

Şeyh Gâlib, TG.15/1 (Kalkışım,211)

Gâlib'in başka bir gazelinde felek de bedduadan nasibini alır. Bilindiği gibi güneş doğudan doğar ve batıdan batar. Güneşin batıdan doğması ise kıyametin on büyük alâmetinden biridir ${ }^{20}$ insanlığın kıyameti yaşaması bu dünya hayatının sonu olduğu için korkulan ve gerçekleşmesi arzu edilmeyen bir durumdur. Aşağıdaki beyitte Şeyh Gâlib, âşık-

${ }^{19}$ uğurlamak(uğrulamak): çalmak

20 “... Büyük alametler ise şu hadiste bildirilmiştir: "On alamet meydana gelmedikçe kıyâmet kopmaz. Deccal'ın çıkışı, Hz. İsâ'nın yeryüzüne inmesi, Ye'cuc ve Me'cucun çıkışı, Dâbbetü'l Arz'ın çıkışı, güneşin batıdan doğması, doğuda, batıda ve Arap yarım adasında meydana gelmek üzere yerin batışı, duman ve insanları mahşer yerine sürecek olan ve Aden çukurundan çıkan bir ateşin zuhuru." (Müslim, Fiten, 13). http://www.diyanet.gov.tr/turkish/dy/Diyanet-Isleri-Baskanligi-AnaMenu -dini-kavramlar-sozlugu-92.aspx (10.03.2009) 
lara bir kere bile sevgilinin güneş yüzünü göstermediği için fettan dünyanın güneşinin de batıdan doğmasını ister. Böylece dünyanın düzeni sona erecek felek de âşıklar gibi güneşi hiç göremeyecektir.

Duâm oldur günü magribde dogsun çarh-1 fettânın

Ki uşşâka yüzün göstermedi ol mihr-i rahşânın

Erip bayrama Gâlib sonra tutdum savm-1 hicrânın

Şeyh Gâlib, TG.17/5 (Kalkışım,213)

\section{Sevgilinin yană̆ı:}

Divan şiirinde başlı başına yüzün güneşe teşbih edilmesinin yanı sıra zaman zaman yanak da güneş gibi tasavvur edilir. Yanak kırmız1lığı, beyazlığı, parlaklığı, yuvarlaklığı ve üstündeki ayva tüyleri ile şairin dikkatini çeken bir güzellik unsurudur ve çeşitli teşbihlere konu olur. Yüz ve yanak birbirinden ayrılmaz bir bütünlük meydana getirdikleri için tasavvurlarda da benzerlik arz ederler. Divan şiirinde yanak güneş gibi hayal edildiğinde genellikle bu hayale zülf (gîsû, saç) de rengi, kokusu ve şekli ile ortak olur. Sevgilinin yüzü (yanağı) güneş ya da ay, kaşının hilal olarak tasavvuru yanağın gül, ayva tüylerinin sebz oluşu, üzerindeki ter tanelerinin yağmura benzetilmesi saçın güneş ve ayı zaman zaman örten bulut ya da âşığın gölge(lik) gibi sığındı̆̆ı bir mekân olarak hayal edilmesine sabep olur (Sefercioğlu 1990: 138-150). Ahmedî’nin aşağıdaki beytinde yanak üzerine düşen zülfün görüntüsü güneşin bulut yüzünden gölgelenmesine, kapanmasına teşbih olunmuştur.

$\mathrm{Bu}$ 'anber saç ruh-1 zîbâya düşmiş

Bulıtdan sanki güne sâye düşmiş

Ahmedî, G301/1 (Akdoğan,405)

Yanak-zülf tasavvurlarından biri de gündüz-gece ilişkisidir. Aşağıdaki beyitte şair sevgilinin gül yanaklarını her sabah güneşin oyalandığı, cilvelendiği bir yere, zülfünün kıvrımını ise her gece ayın menzil tuttuğu mekâna benzetir. Bu hayalde sevgilinin yüzü gece ayın, gündüz güneşin ziyaret ettiği çok kıymetli bir güzellik sembolü olarak düşünülmüştür.

Gûşe-i zülfün durur her gice mâhun menzili

Her seher gül ruhlarundur cilve-gâh-1 âfitâb

Kemalpaşazâde, G.41-5 (PB-51'ah) 
Sevgilinin yanağ parlaktır, adeta etrafına nur saçar. Hatta gökteki güneş bile parlaklığını sevgilinin yanağından alır (Avnî, G.23/1). Güneşin dünyayı yakması gibi sevgilinin yanakları da âşı̆̆ın gönlünü yakar. Kızgın güneşten özellikle öğle ya da ikindi sıcağında insanlar nasıl gölgelik yerleri mekân tutarlarsa âşık da sevgilinin yanağının hararetinden onun zülfünün gölgesine sığınır.

Tâb-1 ruhundan eyledi dil zülfüni mekân

Gün germ olunca kendüye edindi gölgelik

Hayâlî, G.263/4 (Tarlan,180)

Güneş 1şınları bitkilerin büyümesi, meyvelerin olgunlaşması için de gereken sıcaklığı sağlar. Aşağıdaki beyitte ise âşığın canı meyveye; sevgilinin yanağ 1 da güneşe teşbih edilir.

Cân mîvesine lezzeti şevk-i ruhun verür Hurşîd pertevinden olur çün semer lezîz

Hamdullah Hamdi, G.32/4 (Özyıldırım, 141)

Bildiğimiz gibi güneş ya da ay suya aksettiğinde hafif dalgalanarak suyun yüzünde görününür. Bu gözlemden hareketle Fuzûlî, güneşe mekân olarak bulutların arkasını değil bizatihi âşı̆̆ın gözünü seçer. Ayrılık acısıyla gözyaşı döken âşı̆̆ın gözünde sevgilinin yanaklarının hayali durur. Onlar bu hâliyle, sanki dalgalanmış suya güneşin aksetmesi gibi görünürler.

Hayâl-i ârızun cevlân eder bu çeşm-i pür-nemde

Nicük kim mevclenmişs suda aks-i âftâb oynar

Fuzûlı̂, G.70/2 (Akyüz,164)

Divan şiirinde güneşin doğuşuyla ilgili zikredilen zamanlardan biri de işrak vaktidir. ${ }^{21}$ Güneş doğduktan sonra kılınan işrak namazı nafile namazlardan biridir. Müslümanların kıbleye yöneldiklerinde namaz

${ }^{21}$ Güneş doğduktan sonra, ufuk hattından $50^{\circ}$ yükselmesinden itibaren başlayan zamana işrak vakti denir. Halk arasında güneşin bir mızrak boyu yükselmesi şeklinde tabir olunan bu vakte dahve-i suğrâ da denmektedir. İşrak namazı ise gün doğduktan sonra kılınan namazdır. Güneşin doğmasından işrak vaktine kadar farz ve nafile hiçbir namazın kılınması caiz değildir. İşrak vaktiyle birlikte, her türlü namazın kılınması helâl olur. Bayram namazlarının kılınma vakti de bu zamandır. http://www.diyanet.gov.tr/turkish/dy/Diyanet-Isleri-Baskanligi-AnaMenu-dini-kavramlarsozlugu-92.aspx (10.03.2009) 
kılarak huzur duyması gibi âşı da âdeta Kâbe gibi kendisine huzur veren güneş yüzü gördüğünde sevincinden namaz kılar. Sevgilinin kaşının ve yüzünün kıble, mihrâb, secdegâh gibi ibadet yönü /yeri olarak tasavvur edilmesinde şekil benzerliğinin yanında sevgilinin âşı̆̆ın nazarında kazandığ1 değer ve onu yüceltme duygusu, yüzün Kâbe olarak tasavvuru, Kâbe'nin müslümanların ibadet için yöneldikleri makam oluşu, kıble ve secdegâhların yönünün Kâbe'ye doğru oluşu, önemlidir (Sefercioğlu 1990: 151).

Tutdı ebrûna yüzin mihr-i izârunla gönül

Kıbleye karşu kılur sanki salât-i işrâk

Bâkî, G.232/3 (Küçük,243)

\section{Sevgilinin gözleri:}

Güneşe benzetilen güzellik unsurlarından biri de sevgilinin gözleridir. Aşağıdaki beyitte şair, sevgilinin güneşe benzettiği gözlerine feleğin her bir parçasını sürme yapmış ve kendisini onun boyunun gölgesini arzu eden toprak olarak tahayyül etmiştir (Çorak 2002: 101).

Çeşm-i mihre tûtîyâ eyler felek her rîzesin

Ârzû-yı sâye-i kaddünle ol kim hâk olur

Neşâtî, G.30/3 (Kaplan,107)

\section{Sevgilinin eli:}

Sevgilinin güzellik unsurlarından bir tanesi de elidir. Gül, ay, terazi kefesi gibi unsurlara da benzetilen el (Kurnaz 1996b: 296) bütün olarak güneşe teşbih edildiği gibi elin ayası beyaz rengiyle güneşin parlakl1ğına, parmaklar ise ondan yayılan ışınlara teşbih edilir.

Ey Hayâlî ola mı şa'şa'a engüştü misâl

Tutalum benzedi horşî̂d eli âyesine

Hayâlî, G.535/5 (Tarlan, 276)

\section{Sevgilinin Vasıfları:}

Divan şiirinde âşığın/şairin gönlünde ve hayalinde ulaşılmaz bir yeri olan sevgilinin güzelliğinin ve güzellik unsurlarının güneşe teşbihinin yanı sıra huyları, mizacı, başta âşık olmak üzere çevresindekilere karşı tavır ve davranışları, gezinip dolaştığı arz-ı endâm ettiği yerlerdeki hâlleri de güneşle ilişkilendirilir. 


\section{Hükümdar sevgili:}

Divan şiirinde güneş-hükümdar ilişkisiyle hükümdara atfedilen özellikler ${ }^{22}$ sevgilinin sıfatlarıyla da benzerlik gösterir. Sevgilinin âşık nazarındaki en üstün ve en önde gelen vasfı âşığın gönlünün hükümdarı olmasıdır. Kainâtı muhteşem bir saray gibi tahayyül eden Tanpınar, aşkın, zihnî hayatın, hayvanlar ve bitkiler âleminin, kozmik nizamın, varlığın ve yokluğun, velhâsıl bütün mefhumların bu devâsâ sarayın içinde teşekkül eden başka başka saraylar olduğunu hepsinin de hükümdarlarının bulunduğunu belirtir: "Aşk, zihnî hayat, hayvanlar ve bitkiler âlemi, kozmik nizam, varlık hatta adem, bütün mefhumlar, vücudumuzun kendisi, hepsi saraydır. Hepsinin hükümdarlar vardır. Bütün ortaçă̆ ve rönesans edebiyatlarında ve hayal sistemlerinde görülen bu saltanatlarm bir kısmı her kültürde birbirinin aynıdır. Hayvanlar arasında en gösterişlisi olan

22 “Divan şiirinde güneş padişah, sultan olarak karşımıza çıktığında gökyüzü ülke veya savaş meydanı olarak tasavvur edilir. Güneş karanlıklar ülkesini zapteden altın kılıçlı bir hükümdardır. Onun gökyüzündeki gücü ve hakimiyeti, 1şıklı padişah, doğunun hükümdarı, altın sırmalı kaftan giymiş sultan gibi ifadelerle anlatılır. Ayrıca saadet, devlet, kerem, himmet gibi saltanata ve ilâhî güce ait sözcüklerle birlikte kullanılması onun eski dinlerdeki yarı ilahî, yarı beşerî varlığının Müslüman Türk kültüründe de devam ettiğinin bir göstergesi sayılabilir. Klasik Osmanlı şiirinde güneş mazmunlarda sultan olarak kullanıldığı gibi bazı mesnevîlerde eserin kahramanı bir sultan, bir şehzade olarak okuyucunun karşısına çıkar. Gelibolulu Âlî́nin Mihr ü Mâh adlı alegorik mesnevîsinde güneş bir aşk öyküsünün kahramanı olan bir sultandır... Güneş, başında zerrinden bir tâc, sırtında ipekten bir elbise, sırma saçlı, gözü sürmeli olarak betimlenir. Cömerttir, adildir, lütufkârdır. İyi huylu, ilim sahibi, fazilet ve kemal ehlidir. Burada bir noktanın altını çizmek gerekir: Güneş hemen bütün dünya mitolojilerinde üçlü bir rol üstlenmiş gözükmektedir: yaratıcı, koruyucu ve yok edici. Güneşin yaşam sağlayıcı gücü, onu adeta bir yaratıcı konumuna getirmiştir. Bunun bir örneği Mısır mitolojisinde M1sır'ın ilk kralı olarak kabul edilen Re'nin aynı zamanda dünyanın yaratıcısı olarak görülmesidir. Bu niteliğiyle eski inanç sistemlerinde ve mitolojilerde tanrılaştırılmış bazen de koruyucu sıfatıyla dünya hükümdarı olmuştur. Yaşamın devamını sağlaması, ama zaman zaman da 1sısı ve yakıcı 1şığıyla kuraklıklara neden olması güneşi aynı zamanda yok edici ve çekinilen bir unsur hâline getirir. Bu özellikler Osmanlı kültüründe devlet yapısı ve yöneticilerin kişiliği hakkında bilgiler veren ahlak ve siyaset kitaplarında hükümdarların temel nitelikleri olarak yer almaktadır. İyi bir hükümdar gücünün bilincinde olmalı ama bu gücü teb'asının refahı ve devletin bekası için kullanmalı, gerektiğinde yine devletin bekası için yok edici olabilmelidir. Âlî́nin mesnevîsindeki adil, lütufkâr, cömert güneş-padişah bütün bu özellikleri taşır." (Sabuncu 2004 : 289-299). 
aslan, çiçekler arasında gül böyledir. Kalb âleminin hükümdarı da sevgilidir. Bu sistemde hükümdara dolayısıyla sevgiliye asıl hususiyetini veren güneştir. Ortaçă̆ hayallerinde hükümdar daima güneştir. Onun gibi kendi menzilinde ağır ă̆ır yürür. Rastladığını aydınlatır. Gül bulunduğu yeri tıpkı güneş gibi parıltısıyla bir merkez, bir nev'i saray yapar. Hayvanlar âleminde aslanın hükümdarlı̆̆ı da yüzü güneşe benzediği içindir. Böylece hükümdara dolayısıyla güneşe benzeyen sevgili onun ünvan ve vasıflarmı, kudretlerini elbette ki taşıyacaktır (Tanpinar 1988: 5).

Özellikle hükümdar övgüsünde yazılan güneş redifli kasidelerde bu bakış açısının en güzel örnekleri görülebilir, bu kasidelerde hükümdargüneş-sevgili tasvirlerinde göklerin hakimi güneş, yeryüzünün hakimi hükümdar ve âşıkların gönüllerinin hakimi sevgilide hükümdarlık vasıfları iç içe geçmiştir (Gülhan 2005: 299). Gönül ülkesinin hükümdarı sevgili olunca onun nâçiz kölesi olan âşıklar da beyitlerde gedâ, çâker, bende, köle sıfatlarıyla karşımıza çıarlar. Âşıklar sevgilinin kapısında nöbet bekleyen asker, çavuş, nöbetçi veya hizmetçidir. Hükümdar/sevgili âşığa istediği gibi hükmeder. İsterse ihsanda cömertlikte bulunur. Onun ihsanı ancak didârını göstermesi şeklindedir. O yüzünü gösterdiği vakit ondan yayılan nur, ziya her tarafı kaplar, gözler başka bir şey göremez olur. Güneş, gündüz yükseldiği en son noktada gözleri daha çok kamaştırır, kendisine bakılamaz. Hükümdar olan sevgilinin de göz alan güzelliğiyle gözüne, yüzüne bakılamaz. Nitekim Osmanlı sarayında da padişahın huzuruna girildiğinde onun yüzüne bakmadan konuşmak bir protokol geleneği olarak bilinir. Sevgilinin/hükümdarın, âşı̆̆ın/halkın nazarında itibarı yüksektir, baş üzre yeri vardır. Güneş de gökyüzünün hükümdarı, yıldızlar ordusunun kumandanıdır. Hükümdarın dolayısıyla devletin manası halkın mevcudiyeti anlamına geliyorsa gökyüzünde ayın ve yıldızların görünmeleri güneşe, aşkına muhatap olan sevgili sayesinde âşıklık vasfını kazanan âşığın da mevcudiyeti sevgilinin varlığına bağlıdır.

Hükümdar/sevgili, halkın/âşığın gözbebeğidir. Saygıda kusur edilmez, baştan ayağa göz kamaştıran ihtişamıyla halkın/âşı̆̆ın gönlünde taht kurar. Hükümdarla birlikte hatırlanan mekânlar nasıl saray ve taht ise aşk ülkesinin hükümdarı olan sevgilinin de tahtı âşı̆ın gönlüdür.

Hükümdarın fakirlere, ihtiyaç sahiplerine ihsanlarda bulunup onları sevindirmesi gibi güneş 1şıklarının viranhanelere girmesi ile sevgilinin, âşı̆̆ın fakir gönlüne girmesi arasında ilgi kurulmuştur. Böylece sevgili âşı̆̆a dünyaları bağışlamış olur. $\mathrm{O}$, mutluluk ve saadet, himmet ve inâyet menbâıdır. Katında naçiz zerreler mesabesinde olan âşıkla- 
rını/kullarını himmetiyle yüceltir. Kapısı, eşiği kutludur. Cihanı süsleyen hükümdar sevgilinin şöhreti dört tarafta bilinir. Onun şöhreti duyuldukça düşmanların yüzleri sıkıntıdan kararır.

Nedîmâ bî-vücûduz himmet-i mahdûma muhtâcız

Görünmez zerre-i nâçizler mihr-i dırahşansız ${ }^{23}$

Nedim, G49/4 (Gölpinarl, 292)

Ola adûlarunun sâye gibi yüzi siyâh

Sen oldugunca cihânda güneş gibi meşhûr

Hayâlî, K.1/29 (Tarlan,28)

Pâyına yüz süren o şehün kâm-yâb olur

Bir zerre ise mihri ile âftâb olur

Şeyhülislam Yahya, Nazm6/1 (Kavruk, 497)

\section{2. Âşıkların/rakiplerin hânesine hercâyî giren sevgili:}

Güneş 1şıklarının karanlık cihanı aydınlatması gibi sevgili de âşığın gönül hanesine gelerek onun karanlık dünyasını aydınlatır. Güneş ışıklarının adetâ bir nehir hâlinde her haneye girmesi gibi sevgili de âşıkrakib ayırt etmez, dolaşır (Yahya Bey,K5/6). Sevgili kararsız, hercayi gönüllüdür. $\mathrm{O}$, bir zaman âşıkların gönül hanesinde salınırken bir zaman ağyar hanesinden nikâbsız çıkar. Sevgilinin hercayiliği ile bir yerde karar eylemeyen daima devreden güneş arasında; rakibin hanesinden örtüsüz çıkan sevgili ile de gece örtüsünü üstünden atıp sabah aydınlığına çıkan güneş arasında benzerlik kurulur. Sevgilinin rakiplerin hanesinden örtüsüz çıkışı hayra alamet olmadığından güneşin batıdan doğuşuna benzetilir.

Subh-veş rûşen olup dil gün toğardı başuma

Ben yaturken hücreme gelsen seher ey âfitâb

Zâtî,G.72/2 (Tarlan,72)

Hâne-i ağyârdan çıkdı çün ol meh bî-nikâb

Öyle sandum toğdı mağrib menzilinden âfitâb

Emrî,G.46/1(Saraç,35)

${ }^{23}$ Bu mısra Gölpınarlı incelemesinde "mihr-i dırahşânımız" diye tamamlanmaktadır. 


\section{Teşrifiyle uğur getiren sevgili:}

Halkın eşref saati dediği, en uygun saat, uğurlu vakit anlamına gelen bu zaman şiirimizde şeref-i âfitâb, şeref-i şems gibi ilm-i tencim 1st1lahı olarak kullanılır (Onay 2007: 373). Güneşe benzeyen sevgilinin âş1ğın hanesine gelişi de âşık için en uğurlu, en şerefli vakittir.

Çün tâze oldı gül şeref-i âfitâb-1la

Teşrîf eyle bâğa ki vakt-i şerîfdür

Ahmedî, G.224/3(Akdoğan,361)

\section{Mă̆rur sevgili:}

Gönül ülkesinin sultanına "pâdişehüm" diye seslenen Bâkî, yüz güzelliğinden dolayı mağrurlanan sevgiliyi güneşe benzetirken güneşin akşam zeval bulması yok olması gibi kendi güzelliğinin de zamanla kaybolacağını hatırlatarak gururlanmamasını söyler.

Magrûr olma pâdişehüm hüsn-i sûrete

Bir âfitâbdur ki serî'u'z-zevâldur.

Bâkî,G.100/2 (Küu̧ük,162)

\section{Nazlanan sevgili:}

Niyâz ile bekleyen âşıklara sevgisini ve merhametini göstermekte nazlanan sevgili naz güneşine (Nedim, G.37/3) benzer. Ayda y1lda bir görünen o naz güneşi hasretiyle âşıkları harâb eder (Tabîbî, PB 54ah), naz güneşi âşıklara göründüğü vakit de heyecandan benizleri sararır, ayakları kesilir.

\section{Cezbeden sevgili:}

Cihanın güneşe cezbeyle tutulması gibi güneş kadar güzelliğiyle cezbeden sevgilinin yüzüne de âşıklar tutulmuştur.

Güneşte varsa cazibe senin yüzünde yok mudur

Cemâline gönül gibi cihânın incizâbı var

\section{Lâedri}

Hasretiyle âşığını ateşlere atan, can yakan sevgiliye âh etmek boşunadır. Güneşin yaktığı nasıl tütmez, dumanı çıkmazsa hasretle yanan âşığın da âhı boşunadır, sevgiliye ulaşmayacaktır (Fuzĥlî,G.264). Göz- 
yaş1-yıldız, güneş-sevgili ilgisinin kurulduğu aşağıdaki beyitte, güneş çıkınca yıldızların kaybolması gibi âşığın da merhametsiz sevgili belki merhamete gelir diye gözyaşı döktüğ̈̈ ifade edilir.

Yaşumı görüp terahhum idesin dirdüm velî

Agladugum bu ki gün görinse ahter gizlenür

Necâtî Beg,G.124/2 (Tarlan,221)

\section{Terkeden sevgili:}

Güneşin yeryüzündeki devri, gündüz görünüp akşam kaybolmasıyla sevgilinin âşıktan uzaklaşması arasında ilgi kurulur. Gündüzleri görünüp geceleyin ortadan kaybolan güneş, ayrı geçirilen gecelerde hicran derdiyle âşı̆̆ı terkeden sevgilidir. Matem tutan âşık üstüne gece elbisesini karaları giyinir (Üsküplü İshak Çelebi,G.103/3). Kendisiyle bir gece dahi akşamlamayan o âfitâb(Rahîkî, PB 58ah)dan uzak kalan âşı̆̆ın âhı sabaha kadar gökyüzü aynasını paslandırır, karartır.

İy yüzi güneş senden rrah her gice tâ subh

Çarh âyinesin jenge boyar Ahmedî ahı

Ahmedî, G.662/9 (Akdoğan, 584)

Sabah doğuşundan akşam batışına kadar çeşitli görünümleri ve gökyüzünde oluşturduğu renk cümbüşüyle şairin hayal dünyasına yansıyan güneş; yükseldikçe göz kamaştıran güzelliğiyle büyüyen büyüdükçe güzelleşen bir sevgili; sabah, şafak kızıllığında başına al duvaklar bürümüş ya da altın taç takmış mavi tahtında oturan bir gelin, başında altın üsküflü bir güzel, altınlı kabâlarıyla sarı elbiseli bir güzel, kâh şafak vakti gökyüzünün mavi elbisesini giyinmiş kâh grup vakti kırmızı elbisesiyle cihânı yakan bir güzeldir.

\section{Büyüdükçe güzelleşen sevgili:}

Güneş yükseldikçe ısısı artar, dünyayı daha çok aydınlatır, 1şıklarını daha fazla alana yayar. Tan yerinden gittikçe yükselen yükseldikçe göz kamaştırıcı güzelliğe bürünen güneşin bu hâli büyüdükçe güzelleşen bir sevgili gibidir (Mesîĥ G.43/3). O sevgili büyüdükçe güzelliği artar ve şöhreti âleme yayilır.

Ol tıfl-1 mâh-rû kim âyet-i nûr oldı gitdükçe

Şu'â-hüsn ile gün gibi meşhûr oldı gitdükçe

Tecellî, G.102/1 (Deniz, 284) 
Hüsni artarsa 'aceb mi ser-firâz oldukça yâr

Kim ziyâsın artırur yükseldügince âfitâb

Derûnî İzikî / 41-7 (PB-51'b)

\section{Sevgiliyle ilgili maddi kültür unsurları}

Türk kültüründe güneş ve ay motifleri süs, giyim-kuşam eşyaları, ev eşyaları ve paralar üzerinde oldukça sık kullanılan motiflerden ikisidir. Elbise motiflerinde güneşle karışmaması için ay daha çok hilal şeklinde gösterilir. Ay; tennûre, elbise cebi, bel kemeri, küpe, gerdanlık, mehçe, halhal ve nalça; dolunay ise nurdan tac, altın üsküf, külah, akçe, gözlük (Çelebioğlu 1991: 190) olarak tasavvur edilirken güneş de benzer şekilde elbise, elbise motifi, tâc, yüzük, altınlı yüzük kaşı, düğme, küpe, altın üsküf, külah gibi eşyaların yerine geçerek övülenin güzelliğinin bir parçası olur. Güneş ve ay eşyalar üzerinde bir desen şeklinde tasarlandığı gibi eşyanın kendisi de güneş ve aya benzetilebilir. Güneş; rengi, parlaklığı, değeri, biçimi sebebiyle sevgilinin/övülenin kullandığı değerli eşya olabilir. Şimdi beyit örnekleriyle bu benzetmelere değinilecektir.

\section{1. altın üsküf ${ }^{4}$ :}

Klasik Türk şiirinde altın üsküf, başta sevgili ve padişah olmak üzere genellikle saray mensuplarıla (kapıc1, meşaleci, silahdar, solak, sipahi vs.) birlikte anılır. Sırmalı görüntüsü ve parlaklığıyla çeşitli benzetmelere(alem, altın fanus, ateş, ay, çanak, gül, güneş, hâle, kıvılcım,

24 “Üsküf (<İtal.scuffa, Rus. skufiya, Gr. Skoúfıa, Yun. skuphia) “başlık, ibik, hotoz, tepesi devrik ucu püsküllü başlık anlamına gelir. Beyaz renkli, külah biçiminde olup genellikle keçeden yapılan; başa giyilen kısmı sırma işlemeli ve bir bölümü arkaya yatık yeniçeri börkünün bir çeşididir.Altın işlemeli bölümü dört parmak eninde, geriye kalan kısmı arkaya yatık bölümüyle birkilte bir endazeden $(65 \mathrm{~cm}$.) uzundur." (Zülfe 2005: 167-190).

"Altın sırmalı üsküf Kapıkulu piyadeleri tarafından giyilen bir çeşit başlıktı. Hoca Sadedin Efendi'nin anlattığına göre Apolonya kalesinin fethinde elde edilen ganimetler arasında yeniçerilerden birinin eline de altın bir tas geçmiş. Yeniçeri tası saklamak için çaresiz başına geçirerek sarı̆̆ı üzerine sarmış bu hâl dikkat çekip iş anlaşılınca yeniçeri padişahın huzuruna çıkarılmış. Ancak bir lütuf eseri Sultan Murad tası kendisine bırakmış. Ayrıca altın tas ve sarığın görünüşü padişahın çok hoşuna gittiği için bunun resmî serpûş şekli olmasını istemiş." (Şentürk 1995: 90). 
mum alevi, nergis, sancak, yıldız, altın kadeh vb.) konu olur (Zülfe 2005: 173). Üsküf, şekli, altın sarısı parlaklığı, kıymeti, baş üstünde bulunması, güzelliği artırması gibi özellikleriyle güneşle benzerlik arzeder. $\mathrm{O}$ ay yüzlü sevgili ne zaman başına altın üsküf giyse dünyayı güneş gibi yakar (Yahya Bey, ŞEH.2/134.); altın üsküfünü giyip her seher arz-1 endam eden sevgilinin güzelliği karşısında âşık divane olur.

Karşusında yakamı çâk iderem subh gibi

Her seher geyse o meh gün gibi altun üsküf

Sabâyî (Abîdî, Mecmu 'a-i Eş 'âr, 84b) (Zülfe 2005: 183)

\section{2. ayna:}

Eski kültürümüzde ayna çeşitli kullanım alanlarıyla zaman zaman divan şiirine konu edilir. Bunlar arasında aynanın süs malzemesi olarak kullanılması, sokaktan gelip geçeni göstermesi amacıyla dükkanların önüne yuvarlak aynalar asılması, ölmüş olduğundan şüphelenilen kişinin ağzına ayna tutularak nefesinin kontrol edilmesi, papağanlara konuşma öğretilirken kafese ayna asılması ve ardından seslerin telaffuz edilmesi, büyücülerin kehanet için aynalara bakması sayılabilir (Pala 1990: 61). Klasik Türk şiirinde İskenderle birlikte zikri geçen efsanevî unsurlardan biri de âyine-i İskender'dir ${ }^{25}$ (Tökel 2000: 202-203).Tasavvufî anlamda âlem; vahdetin kesret hâlinde aksettiği, vücûdun yokluk olarak yansıdığı bir aynadır. Şeyh Gâlib’te insan-1 kâmil, mümin, mürşit, gönül ve âlem de ayna olarak telakki edilir (Güler 2004: 121). Ayna güneşten kinaye olarak âyine-i çerh, âyine-i âsmân, âyine-i hâverî gibi sıfatlar da alır. Aynanın güneşle ilgisi ise rengi, şekli ve işlevi sebebiyledir. Eskiden cam aynalarla beraber ince, levha hâline getirilmiş demir, gümüş veya altından yapılma yuvarlak aynalar da vardı. Bu yüzden ay gümüşten, güneş de altından bir aynaya benzetilmiştir (Çelebioğlu 1991: 190). Ay-

25 “... İskender, İskenderiye şehrini Belinas'a birakarak gitmeden önce şöyle dedi: “Ey Belinas! Bu şehirde yüksek bir yapı yap ve üstüne bir ayna koy ki bir aylık yoldan her gemi o aynada görünsün. Belinas, Hermis ve Valis üçü bir arada o aynayı yaptılar, doğru dürüst göstermedi. Sonra gümüşten yaptılar, yine olmadı. Sonra bakırdan ve her cins madenden yaptılar yine olmadı. On, sekiz, altı ve dört köşeli yaptılar yine olmadı. Sonra Belinas: 'Şimdi aynayı yuvarlak yapalım, o zaman doğru dürüst gösterir.' dedi. Öyle de yaptılar, görüş düzeldi..." (Tökel 2000: 202203). 
nanın edebiyatta kullanılış sebeplerinin başında bir süs malzemesi oluşu gelir. Güzeller aynaya bakarak kendi güzelliklerinin farkına varırlar, yine ona bakarak süslenirler. Güneş gibi parlak, beyaz, lekesizdir. Berber ve el aynaları genellikle yuvarlaktır, aynaların etrafı altın, pirinç gibi çerçevelerle kuşatılmıştır. Güneşin kâinattaki her şeyi aşikâr etmesi gibi ayna da kendine yansıyan güzelliği ve çirkinliği yansıtır.

Aşağıdaki beyitte ay ve güneş parıltılarını sevgilinin yüzünün parlaklığından alırlar. Dolayısıyla sevgilinin güzelliğini yansıttıklarından güneş onun güzellik aynası felek de ayinedârıdır.

Cemâlün pertevinden nûr-bahş ol mâh u hurşîde Güneş âyine-i hüsnün felek âyine-dâr olsun

Bâkî,G.352/2 (Küçük, 318)

Bazen sevgilinin güzelliğini layıkıyla göstermek için sadece ay ya da güneşin ayna olması yetmez. Prizrenli Şem'i, ancak ay ve güneşin iki ayna gibi bir araya geldiklerinde bu güzelliği yansitabileceklerini söyler. Beyitte doğrudan bir ilgi olmamakla beraber berberlerde bugün de yaşayan ayna tutma âdetini de hatırlayabiliriz. Zira müşterinin saçı kesildikten/yapıldıktan sonra genellikle berber çırağı müşterinin arkasına geçer, iki aynanın görüntüyü yansıtmasıyla başın arka kısmını da müşteriye göstermiş olur.

Cânâ senün gibi güzelin hüsni ayına Lâyık budur ki ay u güneş ola âyine

Prizrenli Şem'i, G.160/1 (Karavelioğlu, 116)

\section{3. kılıç:}

Divan şiirinde güneş 1şıkları ince, uzun, parlak gönünüşüyle kılıç şeklinde de hayal edilebilir. Ahmet Paşa'nın aşağıdaki beytinde ise güneş âşığı gözetleyen eline altın kılıcını almış bir sevgilidir. Eğer âşık sevgilinin ay yüzünden başkasına meyledecek olursa altın kılıcını gösterecek ve ona gözdağı verecektir.

Meh ruhundan gayra tâ kim eylesem meyl-i nigâh

Gözedür zer tîg ile mihr-i cihân-ârâ beni

Ahmet Paşa, G.313/8 (Tarlan, 269) 


\section{4. tâc:}

Türk kadınının baş süsleme malzemelerinden biri olan taç, Türk tarihinin en eski dönemlerinden itibaren kullanılan bir başlık çeşididir. Orta Asya buluntuları arasında yer alan altın levhalar üzerindeki taç başlı kadın figürlerinde saçların ortadan ayrıldığı ve tepede dik duran yapraklı taçlı baş düzenleri görülmektedir. ${ }^{26}$ Osmanlılarda padişahın, resmî günlerde başlarına taktıkları bu murassa başlık (Pakalın 1993: 371) farklı şekillerde ve süsleme biçimiyle Osmanlı saray kadınının da kullandığ1 süs eşyalarındandır. Genellikle elmas, zümrüd, yakut, inci gibi değerli taşlarla süslenen altın taçlar kadın kıyafetinin tamamlayıcısıdır. ${ }^{2}$ Taç, başta altın olmak üzere değerli madenlerle süslenmiş 1şıltılı görünümü ve yükselen sivri uçlarıyla güneşe teşbih edilir. Tacın baş üzre taşınması ve kıymetli oluşuyla da güneşin gökyüzünde insanların başı üstünde olması arasında ilgi kurulur.

Ol gınâ şâhı ki doydu bende olan ac ana

Subh taht-1 acdır hurşî̀d zerrîn tâc ana

Hayâlî, G.12/1 (Tarlan,93)

Ancak kimi zaman güneş sevgilinin altınlı tâc1, felek de firûze tahtı olsa onun ayağının toprağından daha değerli değildir.

Taht-1 pîrûzî felek olursa mihr altunlu tâc

Var-iken hâk-i derün itmez bu gönlüm ihtiyâc

Prizrenli Şem'i, G.23/1 (Karavelioğlu, 52)

26 “...Hun kurganlarında bulunan, kıvrık dal ve çiçek motifleriyle süslü bir taçda kırmızı ve yeşil taşlar vardır... Göktürkler dönemine ait Kudirge buluntularından elde edilen tasvirlerde de üç dilimli taç görülmektedir... Uygur kadınları saçlarını topuz yapıp bunu da bir taçla süslemektedir...Kaşgarlı Mahmud, Selçuklu gelinlerine gerdek gecesi "didim" adı verilen bir taç takıldığından...bahseder." (Şahin 2002: 365).

${ }^{27}$ Batılı yazar ve sanatçıların yazılı eserleri, gravür ve tablolarını Osmanlı kadını açısından inceleyip değerlendiren Gürtuna, Nicolas de Nicolay'dan edindiği değerlendirmeleri şöyle aktarır: Nicolay, sarayda yaşayan kadınla sıradan kadının en büyük farkının baş örtme biçiminde olduğunu söyler; basit bir başlık giyen sıradan kadının yerine saraylı kadının taç taktığını, bu tacın üstünde ve arka tarafta küçük plise bir krep olduğunu başlığın çevresine omuz hizasına kadar sıkan taftadan başlığı iki kere çevreleyen bir tür kordonun yer aldığını yazar (Gürtuna 1999: 15). 


\section{5. tülbend ${ }^{28}$ :}

Divan şiirinde rengi ve başa örtülmesi sebebiyle güneşle-şemsî tülbend arasında ilgi kurulur (Mesîĥ̂ K8/11). Tülbent çeşitlerinden biri olduğunu tahmin ettiğimiz şemsî dülbend ${ }^{29}$ rengi ve üzerindeki desenleriyle güneşe teşbih edilir. Sevgilinin başında güneş renkli/desenli tülbendi görenler sanki gümüş servi üzerine güneş inmiş sanırlar.

Sarınsa şemsî dülbendin güneş gibi güzel Ahmed

Gören dir âfitâb inmiş gümüşs serv-i hırâmâna

Prizrenli Şem'i G.143/4 (Karavelioğlu,109)

\section{6. yüzük:}

Bir başka beyitte övülenin / sevgilinin ferahlık veren eli saadet sabahına, yüzüğü ise parlak güneşe teşbih edilir. Necâtî'nin "avcunun içine almak" deyimini de ustalıkla kullanması onun mahalli söyleyişlerine güzel bir örnektir.

Âlemi ucdan uca avcuna alsan yiridür

Subh-1 devletdür elün mihr-i münevver hâtem

Necâtî Beg, K.19/12 (Tarlan,72)

Sevgilinin süs, giyim-kuşam ve diğer eşyalarından altın üsküf, taç, küpe, yüzük ve aynanın güneşle ilgisi üzerinde yukarıda duruldu. Bunların dışında sevgilinin kullandığı bâzû-bend, düğme, gümüş leğen, sagar, su tası, süpürge, yatak, yastık gibi eşyalar da biçim ve görüntü açısından güneşe benzetilir. Bu beyitlerden bazıları aşağıda kaydedilmiştir.

28 "Pek ince beyaz bez, sarıklık bez"i karşılayan tülbend günlük hayatta tabâbetde kullanıldığı gibi eski Türk giyim kuşamında da sarıklık en makbul bez olmuş, değirmi kesilen parçaları üzerine yazma usûlü ile nakışlar basılarak kadınlara baş yemenileri, namaz bezleri yapılmıştır." (Koçu 1969: 98).

${ }^{29}$ Çiçek çeşitleri ve yaprakları, Lale çiçeği, hurma ve servi ağacı desenleri; geyik, tavus kuşu, kumru, serçe gibi hayvan motifleri ( Kaya 1990: 55) ile çok çeşitli çiçeklerle donanmış hayat ağacı motifleri (Onur 2004: 439) yazmalarda kullanılan motifler arasında zikredilirken güneş deseni yahut güneşle ilgili herhangi bir bilgiye rastlanmamıştır. Ancak en çok kullanılan renkler arasında birinci sırada sarı rengin olması (Kaya 1990: 56) "şemsî" ifadesinin desenden ziyade tülbendin rengiyle de alakalı olabileceğini düşündürmektedir. 


\section{7. bâzûu-bend $d^{30}$ :}

Düşdi sandum âb-1 cârî üzre 'aks-i âfitâb

Bakıcak kolundağı altunlu bâzû-bendüne

$$
\text { Taşlıcalı Yahya, G.392/4 (Çavuşoğlu, 522) }
$$

\section{8. düğme $e^{31}$ :}

Doğdu hurşîdi yine subh-1 bahâr-1 hüsnün

Düğme-i zer degil ol gerden-i kâfur üzre

Nedim, G.132/3 (Gölpınarl,,340)

\section{9. gümüş le ğen:}

Yumaga la'lün-içün çeşme-i hayvândan elüm

Yaraşur ay u güneş olsa gümüşden legenüm

$$
\text { Prizrenli Şem'i, G.116/7 (Karavelioğlu, 97) }
$$

10. sagar:

Şafak mey mihr ü meh sağar habâbıdır anun encüm

Elimde mest-i aşkem iki 'âlem bir ayagımdır

Hayâlî, G.59/4 (Tarlan,109)

\section{1. su tası:}

Yahyâ su koymağ içün ayagına ol mehün

Gûyâ ki tâs idindi felek mihr-i enverî

Yahya Bey,G.474/5 (Çavuşoğlu, 570)

\section{2. süpürge:}

Şûle-i mihri felek eyledi zerrîn-cârûb

Sen güzeller şehinün yollarını pâk eyler

Prizrenli Şem'i G.66/2 (Karavelioğlu, 73)

\footnotetext{
30 "İçine çoğu kere hastalıklara, nazara karşı duaların, temennilerin, hatta alaylı sözlerin yazıldığı kağıtların bir muşambaya veya balmumuna daldırılmış beze sarilıp korunduktan sonra umumiyetle bir gümüş mahfaza içine konularak pazuya bağlanan kol bağıdır." (Deniz 1992: 175).

31 "Eski Türk giyim kuşamında düğme gördüğü işten başka esvâbın süsleri arasında yer alırdı. Tarihimizde servet ve kudreti temsil eden kimselerin altın tel ve ipek nakışlı en ağır, en kıymetli kumaşlardan kesilmiş esvablarındaki düğmeler, o esvabların maddi kıymetini yükselten elmaslardan, yakutlardan, zümrütlerden yapılmıştı ... Akik, firûze, yeşim gibi kıymetli taşlar ile mercan, altın ve gümüş de düğme olarak kullanılmıştır." (Koçu, 1969: 98).
} 
13. yastık:

Girde-bâlin itmege hurşîdi ar itsem revâ

Gördüm olmış hâbda vakf-1 serüm zânû-yı dost

Fehim-i Kadim, G.25/5 (Üzgör, 338)

14. yatak:

Bu ne şehdür kim yatur hüsnün harîminde idüp

Mihri bâlin mâhı pister kâkül-i müşkîn-i dost

Revânî, G.32/5 (Avşar, 110)

Güzellerin bayram günlerinde bindiği dönme dolap ve sevgiliye hediye olarak verilen altın, elbisesinin motifleri, sofrasına konan kebap gibi maddi unsurların da rengi, biçimi, kıymeti itibariyle güneşe benzetildiğini müşahade etmekteyiz.

\section{5. dönme dolap ${ }^{32}$ :}

Döner hurşîd-i âlem tâbına gerdûn-ı gerdânun

Binüp dolaba her bir mâh-1 tâbânı Sitanbulun

Şeyhülislam Yahya,G.195/3 (Kavruk,219)

16. eşrefî̀ $\hat{\imath}^{33}$

Aluben mihr eşrefîsin ağzına pîr-i felek

Ey kamer-ruh müşterîdir vaslına zer gösterir

Hayâlî, G.116/4 (Tarlan,129)

\footnotetext{
32 "Eski bayram yerlerinin fevkalade rağbet gören eğlencesinin de gayet büyük dönme dolap olduğu anlaşılıyor. Bayram yerinde atla dolaşan veya dönme dolaba binmiş olan mahbub civanlar şanında şairlerimizin güzel tasvirleri vardır.. Mahfil Mecmuasında Tahirül-Mevlevi şunları yazıyor: İstanbul'un Fatih, Sultanahmed, Kadırga ve Saray Meydanı gibi geniş sahaları eskiden bayram yeri ittihaz edilmişti. Oralara gelen çocuklar salıncaklarda sallanırlar, dönme dolaplarda yükselip alçalırlar, mihveri etrafında devreden atlı karacalarda dönerler, atla, merkeble hatta deve ile meydanda gezerler.." (Koçu 1961: 2312).

${ }^{33}$ Eşrefî: Memlûk sultanı el-Melîkü'l-Eşref Baybars tarafından 1425 yılında düka ayarında basılan altın para. Yavuz Sultan Selim'in Misır'i fethinden sonra Misır'da bastırdığ 1 "sultânî" paralara da halk eşrefî demiştir (Kuşoğlu 2006: 78)
} 


\section{7. elbise motifi:}

Ey serâ-perden için tâk-mu'allâ atlas

Hil'at-i benden için mihr ü meh altınlı benek

Necâtî Beg, K.12/12 (Tarlan,54)

\section{8. kebap:}

Bezmün kebâbı olmag içün idünür gıda

Her subh encüm erzenini mâkiyân-1 mihr

Mesîhî, G.79/2 (Mengi, 168)

\section{Sevgilinin çevresindeki kişiler}

\section{1. ana/baba:}

Güneşin baba/erkek olarak karşımıza çıkması bize, genel olarak Türk toplumlarında ay ve güneşin cinsiyetinin değişken olduğunu düşündürmektedir. Zira Altaylar güneşi ana, ayı da baba olarak görürlerdi. $^{34}$

Güneşin anneye benzetilmesi güzelliği ve canlıları besleyici özelliğinden kaynaklanmaktadır. Çocuk anne ve babasından aldığı özellikleri taşır, güzellik de bunlardan bir tanesidir. Güneşi sevgilinin annesine teşbih eden Fuzûlî, sevgilinin güzelliğinin annesinden kaynaklandığını söylerken çocukların aynı zamanda anne tarafından beslendiğine işaret eder. Nitekim güneş de 1şıklarıyla tabiatı, bitkileri besler (Deniz 1992: 170).

Ey yüzü gül gönlegi gül-gûn u donı kırmızı

Âteşîn kisvet geyüp odlara yandurdun bizi

Ay u gündür hüsn bahsinde cemâlün 'âcizi

Âdem oglından senün tek dogmaz ey kâfir kızı

Guyyâ atan meh-i tâbândur anan âf-tâb

Fuzûlî, MH.1/3 (Akyüz, 291)

\footnotetext{
${ }^{34}$ Firdevsî́nin Davetnâme adlı astrolojiyle ilgili eserinde ise güneşin erkek olarak tasvir edildiğini görmekteyiz. Çevresinde güneş ışınlarını temsilen çizilmiş üçgenlerden oluşan bir başlık giymiş olan bu erkek figürünün vücudu simetrik çizilmiştir. İki yanında başlarından tuttuğu iki aslan bulunan bu figürün bacakları insan bacağına benzemektedir ve ayak uçlarını birbirine değdirerek oturtmuştur (Sabuncu 2004: 295).
} 
Nedim, sevgilinin güzelliğini överken onun babasının ve anasının ancak güneş ve ay olabileceğini, güzelliği ve parlaklığıyla bir bakışta güneşi, bir bakışta da ayı andırdığını söyler.

Atan anan senin var ise mihr ü mâhtır cânâ

Ki bir bakışta mihre bir bakışta mâha benzersin

Nedim, Ş.10 (Gölptnarl, 368)

Nedim'in aksine Nev'î sevgilinin güzelliğini ne annesinden ne de babasından aldığını, onun eşi benzeri görülmemiş parlak bir yıldız olduğunu ve bir daha böyle bir güzelin doğmayacağını mübalağa sanatının güzel bir örneğiyle dile getirilmiştir.

Ger kamer mâder olsa şems peder

Togmaya bir senün gibi ahter

Nev'i,G.112/1(Tulum,296)

\section{2. $\hat{a} s ̧ ı k^{35}$ :}

Klasik şiirimizde sevgilinin daima etrafında olan şahıslardan biri âşıktır. Güneşin gökyüzünde olması, sabahtan akşama kararsız dolaşması çeşitli hayallerle âşığa benzetilir. Gökyüzündeki hareketi, yükselmesi, aşk deryasında gezen bir âvâre âşık olarak düşünülmesine vesîle olur.

Yılduzu düşkün garib ü 'âşık-1 bî-çâreyin

Gün gibi deryâ-yı '1şkında gezer âvâreyin

Taşlıcalı Yahya, MH.26/1-1 (Çavuşoğlu, 198)

Ayrıca sevgilinin mekânının göklere yükseltilmesiyle güneş, onun kapısında bekleyen âşık olarak vasıflandırılmıştır.

Şeh-i hâverle sultân-1 nücûm ey hüsrev-i hûbân

İki pür şevk 'âşıkdur kapunda subhgâh ahşam

Hayâlî, G.368/2 (Tarlan, 217)

\section{3. dâye (dadı):}

Işıklarıyla ve isısıyla bahar mevsiminde tabiatı canlandıran güneşin özelliklerinden biri de bitkileri büyütmesidir. Bu gerçekten hareketle güneş anneye, 1şıkları süte, yeni yetişen bitkiler ise süt emen bebeklere

${ }^{35}$ Güneş-âşık ilgisi başka bir makale konusu olarak hazırlanmaktadır. Burada iki örnekle yetinilecektir. 
benzetilir. ${ }^{36}$ Benzer bir ilgi güneş dadı arasında kurulur. Dâye kelimesinin sözlükte "taya, sütnine, çocuğa bakan dadı" gibi anlamlarından hareketle güneş; sevgilinin/övülenin süt annesi olarak tasavvur edilir.

Ol nûr-1 İlâhî ki tufûliyyet içinde

Mihr imiş ana dâye meh imiş ana lâlâ

Karamanlı Nizâmî, K2/27 (İpekten, 82)

\section{4. $\operatorname{defçi}(\operatorname{deff} \hat{a ̂ f})$ :}

Zühre yıldız1 ${ }^{37}$, sevgilinin eğlence meclisinde onu müziğiyle ve raksıyla eğlendiren bir çengîye, güneş ise defçiye $\mathrm{e}^{38}$ benzer.

Meclis-i aşkunda çengî Zühre, deffâf âfitâb

N'eylesün raks itmesün mi zerre-i nâçizler

Bâkî, G.86/4 (Kü̧̈ük,154)

\section{5. dellâle:}

Dellale, bir kadın ile erkek arasında aracılık eden kadınlara denir. Aşağıdaki beyitte güneş ve Zühre, sevgilinin güzelliğini alıcılara anlatan dellalelere benzetilirken sevgilinin güzellikte şöhretinin bütün âlemce bilindiği, bunu tekrar etmenin yersiz olduğu belirtilmiştir.

Afitâb u Zöhreye hüsnün meta'in etme arz

Ana âlem müşteri lâzım degül dellâleler

Hayâlî, G.101/4 (Tarlan, 124)

${ }^{36}$ Leben-i mihr akıcak bürc-i Hamelden hâke

Tıfl-veş meyl eder a'lâya nebât-ı efsel

Bursalı Rahmî (Küçük 1988: 159).

37 “ Nâhid, Çobanyıldızı, Venüs, Sa'd-ı asgar (küçük kutluluk) sayılır. Bu yıldızın tesiri altındaki burçlarda doğanlar güzel, zarif, zevk sahibi, zeki, maharetli ve sanatkâr olurlar. ...Feleğin sâzendesi olarak bilinir. Efsaneye göre İranlı çok şuh ve güzel bir kadın imiş. Hârut ve Mârut adlı meleklerden göğe yükselmenin yolunu öğrenip oraya çıkmıştır. Yunan mitolojisine göre aşk ve müzik tanrıçası Afrodit veya Venüs işte budur. Gök ile gündüzün kızıdır. ...bu yıldıza bakmak gönlü ferahlatır ve ruha neşe doldururmuş. Divan şiirinde çok zaman şarkı, aşk, güzellik ve çalg1 ile birlikte anılır." (Pala 1990: 538).

38 “...Haremde düğün minyatüründe ilkbahar çiçekleriyle dolu Hasbahçe izlenimini veren harem bahçesinde genç servi ağaçlarının arasında havuz kenarında gelindamat ve hizmetliler yer alırlar. Kompozisyonun tam ortasına yerleştirilen içinde iki ördek yüzen selsebil tarzındaki havuzun sol tarafında tef, çeng, ud çalan kadınlar ve ellerinde zillerle oynamaya hazır iki genç kız; sağ tarafında koltuğa yan yana oturmuş çift ve onlara hizmet eden cariyeler yer alır (Gürtuna 1999: 15). 


\section{6. dilenci (gedâ):}

Kimi beyitlerde güneş-köle ilgisinin yanı sıra güneş-gedâ benzetmesine de rastlanır. Sevgilinin kölesi gibi kapısından ayrılmayan bir başka varlık da dilencidir. Dilencilerin çaldıkları kapıdan bir şeyler umması gibi güneş de elinde altın renkli tasıyla sevgilinin mahallesinde gezinen, niyâz ile kapısını çalan, sevgilinin in'âmını ve ikramını arzu eden bir dilenci şekline girer (Usûlî, K2/29). Aşağıdaki beyitte "Şamdan gelmiş" ifadesiyle güneşin doğudan doğması, gecenin ardından ortaya çıkması ve dilencilerin genellikle doğu ülkelerinden gelmesi anlamları kastedilerek güçlü bir tevriye sanatı yapılmıştır.

Şamdan gelmiş yalın yüzlü ışk mahbûbudur

Tâs alıp kûyun gedâlar gibi seyr eyler güneş

Hayâlî, K.5/11 (Tarlan,32)

Osmanlı sarayında adeta bir okul gibi tasavvur edebileceğimiz haremde cariyelerin ciddi bir eğitimden geçtiğini Batılı oryantalistler nakleder. II. Mehmed döneminde Enderun'da iç oğlan olan Giovanni Angiolello, sultanın haremindeki kadınların eğitiminden söz ederken, en kıdemli kadınların yeni gelenlere konuşmayı, okumayı öğrettiklerini, onları şeriat konusunda eğittiklerini; ayrıca öğrenmeye yatkın olanlara dikiş dikmeyi, nakış işlemeyi, harp çalmayı ve şarkı söylemeyi öğrettiklerini, törenleri ve adetleri bellettiklerini anlatır. Sınırları belli bir ortam olan haremde kadınların aralarında yaptıkları sazlı oyunlu eğlenceler onların hayatında önemli rol oynardı. 1634 tarihli "Türk Hareminden Bir Sahne" adlı yağlıboya tablonun altındaki yazıda "seçkin Türk hanımlarının evlerinden çıkmaları ve yabancılarla tanışmaları âdet olmadığından onlar birbirlerini evlerine davet eder; dans, komedi ve benzeri eğlencelerle kendilerini oyalarlar" demektedir (Germaner-İnankur 2002: 153-155). Başka bir oryantalist Olivier de benzer ifadelerle Osmanlı şehir hayatında kadının nadiren sokağa çıktığını başta saray hareminde olmak üzere konak ve yalılarda kadınların iç ve dış hizmetlerini gören hizmetçileri, nedimeleri ${ }^{39}$ olduğunu kaydeder. Kültürel hayatın bu cephesine de

39 "Genç kadınların yüzleri peçeli de olsa sık sık sokakta görülmesi, iyi ve kibar bir hareket sayılmadığı gibi hoş da görülmez. Zira kadın, camiye gitmekten muaftır, evinde mükemmel bir hamamı, bütün hizmetlerini gördürebileceği esirleri, hizmetçileri ve nedimeleri daima etrafında ve emrine âmâdedir." (Olivier 1977: 89-90). 
dikkat eden divan şairi güneşi çeşitli vasıflarıyla sevgilinin çevresinde eğlence meclisindeki hizmetkârlarından sâkî, sazende, hânende ve rakkaselere, saçını süslemek için kapısına gelen meşşata ya da âyinedâra, günlük işlerinde yanında bulunan hizmetçilere benzetir. Bunları da birkaç örnekle değerlendirmeye çalışalım.

\section{7. köle (kul, çâker, bende, cariye):}

Sevgilinin gündelik hayatında ona yardımcı olan hizmetçileri vardır. Sevgilinin âşığın nazarında yeri o kadar yüksek ve yücedir ki gökyüzünün padişahı güneş dahi ay yüzlü sevgiliye köledir (Ahmet Paşa, G.5/1). Gece ve gündüz dünyayı devreden ay ve güneş sevgilinin kapısından hiç ayrılmayan, orada nöbet tutan iki köledir. Güneşin çeşitli görünümlerine göre bu kölelerin vasıfları dile getirilir.

Karanlık bir gecede gökyüzünde görünen dolunay beyaz, sarı ya da kırmızıya çalan parlak görünümüyle güneşle benzerlik arz eder. Şair bu gözlemden hareketle gökyüzünün iki müdavimi ay ve güneşi, sevgilinin/övülenin kapısında gece ve gündüz münavebeyle hizmet eden iki sarışın köleye;

Gice gündüz âsitânunda gelür hidmet eder

Mâh u hûrşid iki kullarun dururlar sarışın

Necâtî Beg, K.20/48 (Tarlan,78)

İpi yahut zinciri andıran ışıklarıyla güneşi boynu bağlı köleye;

Boynı baglu kul itdi hurşîdi

Ki şuâı durur resen derler

Çâkerî, G.16/4 (Aynur, 98)

Altın sarısı rengiyle altın üsküflü köleye ${ }^{40}$;

\footnotetext{
40 "...Bir başka ifadesinden de saray ve iç oğlanlarının dışarıdan gelenlerle görüşmek için Hasoda hizmetlilerinin "üsküfi", hazine ve kiler hizmetlilerinin de "çatma kumaştan takye" yi başlık olarak giydiklerini öğrenmekteyiz. (Şeker 1997: 163).

"Koru ağasının merasimde giydiği (düzbörk) beyaz keçe külahtır. Yeniçerilere mahsus olanın önünde kaşıklık vardır. Yeniçeriler yemek yedikten sonra kaşığı buraya korlardı. Enderunda giyilen üzeri sırma işlemeli ve altınlı börklere üsküf denirdi. Yeniçeri bölükbaşıları arasında da maruf olan ve Bolavar muharebesi sonunda kullanılan uzun tüylü (Skota)dan galat olarak alınan üsküf isimleri bir fakat ayrı başlıklardı." (Cenkmen ts : 256).
} 
Altun üsküflü kulun olsa n'ola mihr-i felek

Pâdişâh-1 âlem-ârâsın bugün ey âfitâb

Hilâlî/41-38 (PB-53 bh)

Toprağa yansıyan 1şıklarıyla sevgilinin eşiğine yüz süren köleye

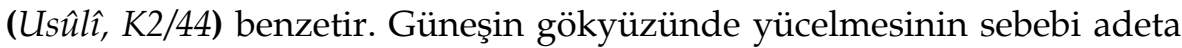
toprak gibi sevgilinin kapısında kul olmasındandır (Şeyhülislam Yahyâ, K3/21).

Saray yahut konaklarda hizmetçilerin vazifelerinden biri de han1mı/beyin elini yüzünü, ayağını yıkarken ibrik, leğen, havlu gibi malzemeleri hazır bulundurmak ve yıkama işlemine yardımcı olmaktır. Ev sahibinin bu tür özel hizmetini görmek hizmetliler arasında bir iftihar vesilesi dahi olabilir. Zira evin hanımının/beyinin özel hizmetinde bulunmak herkese nasip olmaz. Aşağıdaki beyitte güneş, elinde altın tas ile sevgilinin ayağına su dökmeye bile layık olmayan bir hizmetçiye benzetilmiştir. Aynı şekilde hilal şeklen parmağa benzese de sevgilinin kınalı bir parmağı kadar kıymeti yoktur.

Şafakda mâh-ı nev hınnâlu bir parmagına degmez

Güneş zer tas ile su koymaga ayaguna degmez

Emrî, G.211/1 (Saraç,118)

\section{8. meşşatalâyinedâr:}

Osmanlı toplumunda süslenme arzusuna hizmet eden, özellikle saç düzenlemesi ve yüz yazısı konusunda fevkalade estetik maharetleri olan kadınlar vardı. Bunlara meşşata ya da başlıkçı adı verilirdi. Önceleri İslam kadınları meşşatalık yaparken daha sonraları Rum hanımlar bunu gayri resmî bir meslek olarak devam ettirmişlerdir. Ekseriya sosyeteye hizmet veren meşşatalar yalıların, konakların ve hamamların gediklisi idiler. Meşşataların yanında ona yardımcı olan, ayna tutan halayıklaramüstakbel meşşatalara-âyinedâr adı verilirdi. ${ }^{41}$ Aşağıdaki beyitlerde

\footnotetext{
${ }^{41}$ "Başlıkçılar düğün evlerine yükte hafif bahada ağır bir mücevher çekmecesi ile giderlerdi. Başlıkçılık tehlikeli iş ve şöhret olmuştur. Süleymaniyede bir konakta oturan ve elmaslarının çokluğundan ötürü "yarım İstanbul" lakabı ile anılan Başlıkçı Cevriye Hanım, 1839'da zenci bir halayığı ile (âyinedâr) beraber mücevherleri yüzünden öldürülmüştü. ...Ayinedâr...süsleme, çeki düzen verme ve tıraş işinde ayna tutan kimseye verilen isimdir. Ekseriyetle Hindulara, yani kölelere düşen bir vazife olarak görülür. Demek ki meşşatanın bir yamağı da vardır. Meşşata eski toplumumuzda süslenme arzusuna hizmet eden, özellikle baş düzenlemesi ve yüz
} 
toplumdaki bu kültür hatırlatılarak her sabah sevgilinin kapısına gelen ve sevgilinin yüzünün güzelliğini ortaya çıkaran güneş, onu süslemek için konağın kapısına gelmiş meşşataya ve onun yardımcısı âyinedâra benzetilir. Güneş meşşata olduğunda sarı renkli ışıkları da meşşatanın elzem malzemelerinden biri olan tarak olur.

Meşşâtavâr âyinesine cilâ virüp

Aldı eline şâne-i zerrîn âfitâb

Revânî K.1/13 (Avşar,25)

Eline âyine almış güneş gelür her subh

Kapu kapu gezen âyinedâra benzetdüm

Çâkeri, G.84/3 (Aynur,172)

\section{9. rakkâse:}

Sabahtan akşama doğudan batıya hareket eden güneş bu dönüş hareketiyle âdetâ rakkaseyi andırır. Onun görevlerinden biri de sevgilinin eğlence meclisinde rakkaslıktır. Zühre bu mecliste her gün çeng çalarak güneşe raks yaptırır.

"Bezm, peymâne, sâkî, çeng, oynamak" kelimeleriyle güzel bir tenasübün kurulduğu beyit şöyledir:

Sâkiyâ peymâne sun kim şevkıne şeh bezminin

Zöhre her gün çeng ile hurşîd-i tâbân oynatur

Ahmet Paşa G.38/4 (Tarlan, 137)

Aşağıdaki beyitte ise rakkase güneşin özellikleri tavsif edilir. Işıkları sarı saça, kendisi de parlak bir yüze teşbih edilen güneş sevgilinin meclisindeki sarı saçlı melek yüzlü rakkaseyi andırır.

İy şeh-i meh-ru gelüp bezmüne yer yer yanmaga

Bir saru saçlu melek yüzlü güzeldür âfitâb

Tarîkî/41-30 (PB 53a)

yazısı konusunda fevkalade estetik maharetleri olan tecrübe sahibi bir kadındır. Önceleri daha ziyade kocasıyla iyi geçinen ve başından tek nikah geçmiş bir islam kadını iken bilahare baş yapmak bir meslek hâline gelince gayri müslim kadınlara ve hassaten Rum hanımlara inhisar etmiştir. Bunu gayri resmi meslek hâlinde devam ettiren hanımlar, ekseriya sosyeteye hizmet vermişler ve konakların, yalıların gediklisi olmuşlardır. Daimi adresleri ünlü hamamlar iken hamamlara ün katan meşşatalar da çıkmıştır...o çalışırken müstakbel meşşata olan beyaz tenli yamağ yahut siyâhî halayığı karşısında ayna tutar ( Pala 2004: 394-410). 


\section{0. sâkî:}

İshak Çelebi'de felekler sevgilinin eğlence meclisi, güneş de elinde altın kasesiyle felek meclisinde bin işve ile salınan sâkîdir.

Bu bezm-gâh-1 felekde hezâr işve ile

Elüne ger suna hurşî̀d kâse-i zerrîn

Üsküblü İshak Çelebi, MG.3/9 (Çavuşoğlu,71)

\section{1. türbedâr:}

Mezar üzerine türbe, eyvan veya kubbe yapılması; mezara türbedâr tayin edilmesi geleneğine de işaret edilen aşağıdaki beyitte güneş ve ay gece gündüz sevgilinin mezarında hizmet eyleyen iki türbedâr gibi vasfedilmiştir.

Gündüz birisi hizmetin eyler gice biri

Mihr ile mâh meşhedine oldı türbedâr

Nevî,TB.4/48 (Tulum,187) ${ }^{42}$

\section{E. Sevgiliye öykünen güneş:}

Bu kısma kadar incelediğimiz beyitlerde sevgilinin ya da sevgiliye ait unsurların güneşe teşbihini ele aldık. Yaptığımız incelemede dikkatimizi çeken hususlardan biri de divan şairi emsalsiz güzelliğiyle sevgiliyi överken güneşi de bu güzelliği kıskanan yahut ona benzemeye çalışan biri olarak hayal eder. Bir başkasına benzeme tutumu sonucu örnek alınan kişinin giyim kuşam tarzı, beden dili taklit edilebilir. Güneş de sevgilinin emsalsiz güzelliğine öykünür bu öykünme zaman zaman kıskançlık hududlarına varır. O güzeller şahına benzemeye çalışan güneş kâh altunlu külah takıp kâh altunlu şîb ${ }^{43}$ giyinerek meydana çıar.

Ol şeh-i hûbâna öykinmek diler her gün güneş

Geh geyer altunlu külah geh geyer altunlu şî̉b

Revânî,G.22/4 (Avşar,107)

Güneş özellikle sevgilinin yüz güzelliğine öykünür hatta ben daha güzelim diye gururlanır. Ancak bu gururun onu zevale düşüreceğini

\footnotetext{
${ }^{42}$ Beyitin alındığı kaynak: (Yeniterzi 1999: 115-139).

${ }^{43}$ Eskiden giyim eşyası, yastık örtüsü yapımında kullanılan ince gümüş teller ve ipek iplikle dokunan bir tür değerli kumaş; şip.
} 
hesap edemez (Ahmedî, G.153/2). Bu zeval iki şekilde gerçekleşir birincisi akşam olduğu vakit güneş kaybolur (Mesîĥ̂, G.142/4), ikincisi güneş tutulması yoluyla ayın ardına gizlenir. Çâkerî, sevgilinin yüzüne ve alnına ay ile güneşin benzetilemeyeceğini zira onların husûf ile kaybolduklarını şöyle belirtir:

Ay $u$ gün nice diyem benzer yüzünle alnuna

K'anlarun her birine irer husûf ile zevâl

Çâkerî, G.74/2 (Aynur,162)

Güneş-sevgili güzelliğinin karşılaştırılmasına dayanan bu kurguda güneşin ışı̆̆ının bütün âleme yayılmasının sebebi çok güçlü bir güzellikten -sevgiliden - ışı̆̆ını almasıdır. Sevgilinin güneşin kendisi olması hâlinde güneş de sevgiliden aldığı 1şıkla dünyayı aydınlatan bir kandil (Zuhûrî /41-48, PB54 ${ }^{\text {hh }}$ ), haşre kadar yanacak olan bir çıradır. Haşre dek sönmemesinin sebebi yine 1şığını aldığı kaynağın-sevgilinin güzelliğinin-gücüdür (Vahŷ̂ Efendi/41-49, PB 54hh). Sevgilinin güzelliği nurdan sonsuz bir derya; güneş, ay ve Zühre ise bu deryanın üç damlasından ibarettir ( Zâtî, G.64/2 ). Sevgilinin cihanı yakan güzelliği yanında hiç kimse değil ayı, güneşi bile bir zerre mukabilinde saymaz (Bâkî,G.288/2). Sevgili yüzünden örtüsünü kaldırınca onun can yakan gözleri, kaşları, yanakları, vs. görünür. Onun cihanı aydınlatan bu güzelliği karşısında güneş, ışığını ovalara kırlara düşürür.

Sen yüzünden âlemi rûşen kilup saldun nikâb

Yazıya salsun bugünden böyle nûrın âf-tâb

Fuzûlı̂, G.27/1 (Akyüz,143)

Sevgilinin güzelliğinden murad evvela onun gözleri ve kaşlarıdır. Onlar da güneşte bulunmadığına göre güneş güzellik davasında bulunup sevgiliyle karşılaşmamalı, yüz yüze gelmemelidir (Necâtî,G.137/2). $\mathrm{O}$, sevgilinin güzellik denizinin ancak bir katresi olabilir (Ahmet Paşa, G.22/2). Güzellik meydanında sevgiliyle boy ölçüşmek haddine bile değildir (Bâkî,G.439/4). Sevgili güzellik tacını takındığından beri güneş, altından külahını kızgınlıkla yerlere çalacak (Ahmet Paşa, G.170/2), sevgiliyle yüz yüze geldiğinde onun yüzünün güzelliği karşısında güneş kendi güzelliğinden utanacak ışınlarını parmak yaparak elleriyle yüzünü kapatacaktır. 
Şa'şa'a sanma hicâb idüp ruh-1 dildârdan

Rûyına barmakların tutar Emînî âfitâb

Eminzâde Emînî, 41-56 ( PB-55ah)

Sevgiliye benzemeye çalıştığı için hayretinden duvardaki nakışlar gibi donup kalacak (Behiştî, G.41/3) yahut akşam olmadan zevale erecektir (Emrî, G.297/2). Batan güneşin akşamları kaybolmasının sebeplerinden biri de sevgilinin cemalinin güzelliği karşısında utancından yere geçmesidir (Karamanlı Nizâmî, G.32/3). Ahmet Paşa da sevgilinin güneşten daha aydınlık olan yüzü bütün geceyi aydınlattığı için akşamları güneşin hayâsından kaybolduğunu belirtir. Burada utanan kişinin mahcubiyetinden dolayı pek göze görünmemeye çalışması da ince bir şekilde ifade edilmektedir

Şöyle âlem-tâb olur ruhsâr-1 cânân her gece

Kim hayâdan gizlenür hurşîd-i rahşân her gece

Ahmet Paşa, G.257/1 (Tarlan, 242)

Her sabah doğan güneş sevgiliyle güzellik yarışına girip elinde kıl1cıyla meydana çıkan bir kişidir. Ancak bu güzellik davasında her akşam mağlup olup meydandan titreyerek kaçan yine odur (Karamanlı Nizâmî, G.26/5). "geldikçe" fiiliyle sürekli, tekrar tekrar gelişin anlatıldı̆̆ı beyitte her sabah yeniden doğan güneş güzellik davasında güreşe doymayan pehlivan gibi tasavvur edilir.

Davi-i hüsn eyleyip meydanına geldikçe mihr

Hüsn-i âlem-gîrin ey meh-rû düşürdü anı pest

Hayâlî, G.33/3 (Tarlan,100)

Bilek güreşinin mazmun olarak alındığı aşağıdaki beyitte ise şair, güzelliğinin şöhreti dünyaya yayılmış olan sevgiliyle yarışan güneşi bilek güreşinde mağlup olup elinin arkası yere gelen taraf gibi hayal eder.

Gördi dünyâya sıgışmaz hüsn ile ol mehlikâ

Kodı iy Yahyâ el arkasını yere âfitâb

Yahya Bey,G.24/7 (Çavuşoğlu,296)

Sevgiliye benzemediği için hasedinden tir tir titreyen güneş(Ahmedî, G.125/6) artık bu davadan vazgeçmeli, olmayacak bir şey için halkın başını boş yere ağrıtmamalıdır ( Revânî,G.17/2 ). Hüsn-i ta'lil yoluyla 
sıcaktan buharlaşıp yükselen çiğ tanelerinin gökyüzüne çocuklar tarafından fırlatılan çakıl taşları gibi düşünüldüğü aşağıdaki beyitte eğer güneş güzellik davasında inadına devam ederse gözdağ1 vermek için güller tarafından şebnemlerle taşa tutulacağı belirtilmiştir.

Germ olup benzetdügi'çün kendüyi ruhsârına

Âfitâba jâlelerden oldı seng-endâz gül

Hayâlî,G.307/4 (Tarlan,195)

Cihan, güzellerin satıldığı bir pazar yeri olarak düşünüldüğünde sabahtan akşama kadar dünyayı dolanan güneş de bu pazarı dolaşan kızgın müşteriye benzetilir. "kızgın" kelimesinin tevriyeli olarak kullanıldığı bu beyitte hem güneşin harareti, yakıcılığg hem de istediğini satın almak için pazarda açı artırma usûlüyle alışverişi hararetlendiren müşteriler kastedilmektedir.

Hüsni bâzârın tolanur her seher ahşama dek

Benzer ol meh-rûya kızgın müşterîdür âiftâb

Süvârî, 41-105 (PB-59a)

Bir başka beyitte ise güzellik davasında bulunan güneş güzellik pazarına kendisi çıkar. Ancak bütün yakıcı güzelliğine rağmen kimse onunla ilgilenmez, pazara onu görmeye gelmez; çünkü herkes, bütün cihan ay yüzlü sevgiliye taliptir. Beyitte öğlenin kızgın sıcağında dışarıya çımanın pek tercih edilmemesi bu sebeple alışverişin yahut diğer işlerin yavaşlaması "germ olma kim bâzâr yok" ifadesiyle cinaslı olarak dile getirilmiştir.

Çün cihân ol meh-likâya müşterîdir ey güneş

Satamazsin hüsnünü germ olma kim bâzâr yok

Ahmet Paşa, G.144/7 (Tarlan, 188)

\section{Sonuç olarak;}

Bakmakla görmek arasındaki farkı bilen sanatkar anlayışı ve titizliğiyle çevreyi gözlemleyen divan şairi, toplumun bütün değerlerini, Osmanlının edebî ve kültürel estetiği içinde şiirinde ustaca yorumlamıştır. Eşyanın ve mekânın yeniden yorumlanmasının bir sonucu olarak; bütün canlıların yaşam kaynağı olan güneş, kıymetine oranla divan şiirinin mecazlar atmosferinde yerini almıs, hemen her şair tarafından kullanılmıştır. Klasik Türk şiirinde güneş sevgilinin bir benzetileni olarak en çok 
ilgi kurulan kozmik unsurdur. Bunda ışığıyla, ısısıyla hayatın devamı için vazgeçilmez oluşunun etkisi büyüktür.

Kültürümüzün etkisiyle sevgilinin güneşe teşbihinde güneş; güzelliğin, gücün, hükümdarlığın, adaletin sembolü olarak bilinmekte ve beyitlerde daha çok bu yönüyle ele alınmaktadır. Sevgilinin güneşe teşbihinde iki ana ilgi öne çıkmaktadır:

Birincisi güneş-hükümdar ilgisidir. Sevgili, âşığın/şairin gönlünün hükümdarı güneş de feleklerin hükümdarı, yıldızların komutanıdır. Diğeri güneş- yüz ilgisidir. Sevgili güneş gibi yüzüyle hayat verir, yakıcllığıyla da can alır.

Güneşle ilgili mecazların çeşitliliği, şairlerin gerçek bilgiyle ördükleri hayal dünyasının da zenginliğini gösterir. Divan şairi gökyüzü ve meteoroloji bilgisini, kozmik aleme duyarlılığını, dini literatüre hakimiyetini şairlik gücüyle sanatına yansıtmıştır. Beyitlerde dikkatimizi çeken eşref saati, işrak vakti, kıyamet güneşi gibi zamanla ilgili tasavvurlardan güneşle ilgili bilgi ve inanışlara ulaşmak mümkündür.

Beyitlerdeki anlam zenginliği ve derinliği Klasik Türk şiirinin kısır döngü içinde daima aynı hayaller zinciriyle örülmediğinin bir göstergesidir. Sadece sevgili-güneş benzetmeleri üzerine yapılan bu araştırmayı daha da genişleterek Klasik Türk şiirinin en meşhur tipi sevgilinin güzelliği, güzelliğinin bir parçası (yüzü, yanakları, gözleri, alnı), sevgilinin etrafındaki kişiler ve sevgilinin kullandığı eşyalar ile güneşin biçimi, renkleri, doğuşu, yükselişi, kayboluşu arasında kurulan tasavvurların zenginliği üzerine daha çok şey söylemek elbette mümkündür.

Yapılan bu çalışmada Klasik Türk şiirinde güneşle ilgili benzetmelerin çokluğu ve çeşitliliği bütün malzemenin münferit bir eser içinde toplanacak kadar zengin olduğunu da göstermiştir.

\section{Kaynakça}

Açll, Berat (2008), “Divan Şiirinde Güneş İmgesinin Mahşer Güneşine Evrilmesi", Kritik, I, 116-140.

Akdoğan,Yaşar,http://wwww.kultur.gov.tr/TR/Tempdosyalar/235225_Ahmedidiv aniyasar akdogan.pdf (23.01.2009)

Akyüz, Kenan, Süheyl Beken, Sedit Yüksel, Müjgan Cunbur (1990), Fuzûlî Divanı, Ankara: Akçağ Yay. 
Avşar,Ziya,http://wwww.kultur.gov.tr/TR/Tempdosyalar/235223_RevaniDivaniZi yaAvsar.pdf (23.01.2009)

Ayan, Hüseyin (1990), Nesîmî Divanı, Ankara: Akçă̆ Yay.

Aydemir, Yaşar (2000), Behiştî Divânı, Ankara: MEB Yay.

Aynur, Hatice (1999), 15. yy. Şairi Çâkerî ve Divanı : inceleme-tenkitli metin, İstanbul:(yy)

Bayat, Fuzulî ( 2007),Türk Mitolojik Sistemi, I, İstanbul: Ötüken Yay.

Cenkmen, Emin (ts), Osmanlı Sarayı ve Kıyafetleri, Türkiye Yayınevi.

Çavuşoğlu, Mehmet (1971), Necâtî Bey Divanının Tahlili, İstanbul: MEB Yay.

Çavuşoğlu, Mehmet (1977), Yahya Bey Divanı, İstanbul: İstanbul Üniversitesi Edebiyat Fakültesi Yay.

Çavuşoğlu, Mehmet (1979), Amrî Divanı, İstanbul: İstanbul Üniversitesi Edebiyat Fakültesi Yay.

Çavuşoğlu, Mehmet ve M. Ali Tanyeri (1977), Hayretî Divanı, İstanbul: İstanbul Üniversitesi Edebiyat Fakültesi Yay.

Çavuşoğlu, Mehmet ve M. Ali Tanyeri (1990), Üsküplü İshak Çelebi Divanı, İstanbul: Mimar Sinan Üniversitesi Yay.

Çelebioğlu, Âmil (1991), “Ay / Kültür ve Edebiyat”, DİA, IV, 182-191.

Çelebioğlu, Âmil (1988),“Fuzûlî́nin Bir Beyti Üzerine Bazı Düşünceler”, Osmanlı Araştırmaları, VII-VIII, 199-210.

Çorak, Reyhan (2002), Klasik Edebiyatta Sevgilide Göz, Kirpik ve Kaş Üzerine Benzetmeler, Basılmamış Yüksek Lisans Tezi, Ankara: Gazi Üniversitesi Sosyal Bilimler Enstitüsü.

http://www.diyanet.gov.tr/turkish/dy/Diyanet-Isleri-Baskanligi-AnaMenu-dinikavramlar-sozlugu-92.aspx (10.03.2009)

Deniz, Sebahat (1992), 16. Yüzyıl Bazı Divan Şairlerinin Türkçe Divanlarında Kozmik Unsurlar, Yayınlanmamış Doktora Tezi, Marmara Üniversitesi Türkiyat Araştırmaları Enstitüsü, İstanbul.

Deniz, Sebahat (2005), Tecellî ve Divani, İstanbul: Veli Yay.

Doğan,MuhammedNur,http://www.kultur.gov.tr/TR/Tempdosyalar/235 220_avnfatihdivanimuhammednurdogan.pdf (23.01.2009)

Erzurumlu İbrahim Hakkı (1983), Marifetnâme, Hzl. M. Faruk Noyan, İstanbul.

Eyüboğlu, İsmet Zeki (1987), Anadolu İnançları, İstanbul: Geçit Kitabevi. 
Eyüpoğlu, E. Kemal (1975), Şiirde ve Halk Dilinde Atasözleri ve Deyimler II, İstanbul: Doğan Kardeş Matbaacılık.

Germaner, Semra ve Zeynep İnankur (2002), Oryantalistlerin İstanbulu, İstanbul: Türkiye İş Bankası Kültür Yay.

Gölpınarlı, Abdülbaki (1951), Nedim Divanı, İstanbul: İnkılap Kitabevi.

Güler, Zülfi (2004), "Şeyh Gâlib Divanında Ayna Sembolü", Fırat Üniversitesi Sosyal Bilimler Dergisi, XIV, S.1,103-121.

Gülhan, Abdülkerim (2005), “Güneş Redifli Kasideler ve Övgülerinde Hükümdar Tiplemeleri Üzerine Bir Değerlendirme", Osmanlı Araştırmaları, XXVI, , 297-328.

Gündoğdu, Betül (2002), Pervâne Beg Nazire Mecmuâsı(30a-67b), Yayınlanmamış Yüksek Lisans Tezi, İstanbul: Marmara Üniversitesi Türkiyat Araştırmaları Enstitüsü.

Gürtuna, Sevgi (1999), Osmanl Kadın Giysisi, Ankara: Kültür Bak.Yay.

Güven, Hikmet Feridun (1988), Hayretî Divanında Kozmik Âlem ve Zaman, Yayınlanmamış Yüksek Lisans Tezi, Ankara: Gazi Üniversitesi Sosyal Bilimler Enstitüsü.

İpekten, Haluk (1974), Karamanlı Nizâmî, Ankara: Sevinç Matbaası.

İsen, Mustafa (1990), Usûlî Divanı, Ankara: Akçağ Yay.

İz, Fahir (1999), "Divan Şiiri", Osmanlı Divan Şiiri Üzerine Metinler, Hzl. Mehmet Kalpakl1, 112-133, İstanbul: YKY Yay.

Kalkışım, Muhsin (1994), Şeyh Galib Divanı, Ankara: Akçağ Yay.

Kaplan, Mahmut (1996), Neşâtî Divanı, İzmir: Akademi Kitabevi.

Karacan, Turgut (1991), Bosnalı Alaeddin Sâbit Divanı, Sivas: Cumhuriyet Üniversitesi Yay.

Karavelioğlu, Murat Ali, Onaltıncı Yüzyıl Şairlerinden Prizrenli Şem'i'nin Divaninin Incelenmesi ve Edisyon Kritiği (http://www.kultur.gov.tr/ TR/Tempdosyalar/235222__prizrenlisemi.pdf (23.01.2009)

Kavruk, Hasan (2001), Şeyhülislam Yahya Divanı, Ankara: MEB Yay.

Kaya, Reyhan (1990), "Yazmacılık Sanatında İstanbul Ekolü", Sanat Tarihi Araştırmaları Dergisi, III, 54-58.

Koçu, Reşat Ekrem (1961), "Bayram Yerleri" İstanbul Ansiklopedisi, V, İstanbul: İstanbul Ansiklopedisi ve Neşriyat.

Koçu, Reşat Ekrem (1969), Türk Giyim Kuşam ve Süslenme Sözlü̆̆̈̈, Ankara: Sümerbank Kültür Yay. 
Kurnaz, Cemal (1996a), “Güneş (Edebiyat)”, DİA, XIV, 294-296.

Kurnaz, Cemal (1996b), Hayâlî Beg Divanının Tahlili, İstanbul: MEB Yay.

Kuşoğlu, Mehmet Zeki (2006), Kuyumculuk ve Maden Terimleri Sözlü̆̆̈̈, İstanbul: Ötüken Yay.

Küçük, Sabahattin(1988), “Divan Şiirinde Güneş Üzerine Bir Deneme”, Mehmet Kaplan İçin, Ankara: Türk Kültürünü Araştırma Enstitüsü Yay.

Küçük, Sabahattin (1994), Bâkî Divanı, Ankara: TDK Yay.

Mengi, Mine (1995), Mesîhî Divânı, Ankara: Atatürk Kültür Merkezi Yay.

Olivier,Guillaume Antoine (1977), Türkiye Seyahatnâmesi: 1790 yıllarında Türkiye ve İstanbul, İstanbul: Ayyıldız Matbaası.

Onan, Necmettin Halil (1991), İzahlı Divan Şiiri Antolojisi, İstanbul: MEB Yay.

Onay, Ahmet Talat (2007), Açıklamalı Divan Şiiri Sözlü̆̆̈̈, Hzl. Cemal Kurnaz, Ankara: Birleşik Kitabevi.

Onur, Ozanay (2004), “Üsküdar'da Yazmacılık” II. Üsküdar Sempozyumu Bildiriler, II, 436-443.

Ögel, Bahaddin (1995), Türk Mitolojisi II, Ankara: TTK Yay.

Özkan, Senail (2006), Mevlânâ ve Goethe, İstanbul: Ötüken Yay.

Özyıldırım, Ali Emre (1999), Hamdullah Hamdi ve Divânı, Ankara: Kültür Bakanlığ 1 Yay.

Pakalın, Mehmet Zeki (1993), Osmanlı Tarih Deyimleri ve Terimleri Sözlü̈̆̈̈̈ , III, Ankara: MEB Yay.

Pala, İskender (1990), Ansiklopedik Divan Şiiri Sözlü̈̆̈̈̈, Ankara: Akçă̆ Yay.

Pala, İskender (2004), "Meşşata" Akademik Divan Şiiri Araştırmaları, İstanbul: Kap1 Yay., 394-410.

Sabuncu, Zeynep (2004), “Eski Türk Edebiyatında Güneş Motifi Üzerine Bir İnceleme", Türklük Bilgisi Araştırmaları (Journal of Turkısh Studıes), Harvard University, Volume 28/1, 289-299.

Saraç, M.A. Yekta (2002), Emrî Divanı, İstanbul: Eren Yay.

Saraç, M.A. Yekta (2006), Klasik Edebiyat Bilgisi Belâgat, İstanbul: Gökkubbe Yay.

Sefercioğlu, Nejat (1990), Nev'î Divanının Tahlili, Ankara: Kültür Bak. Yay. Şahhüseyinoğlu, Nedim (2000), Anadolu Halk Kültüründe İnanç Motifleri, Ankara: İtalik Yay.

Şahin, Yüksel (2002), "Anadolu Kadın Başlıkları" Türkler, Editörler: Hasan Celâl Güzel, Kemal Çiçek, Salim Koca, XVIII, 363-376. 
Şeker, Mehmet (1997), Gelibolulu Mustafa 'Âli ve Mevâ'ıdü'n-Nefâis fîKavâ'ıdi'l-Mecâlis, Ankara: TTK.

Şentürk, Ahmet Atilla (1995), Necâti Beğ'in Sultan Beyazıt Methiyesi ve Bazı Gazelleri Hakkında Notlar, İstanbul: Enderun Kitabevi.

Şentürk, Ahmet Atilla (2002), XVI. Asra Kadar Anadolu Sahası Mesnevîlerinde Edebî Tasvirler, İstanbul: Kitabevi Yay.

Tanpınar, Ahmet Hamdi (1988), XIX. Asır Türk Edebiyatı Tarihi, İstanbul:Çağlayan Kitabevi

Tarlan, Ali Nihad (1948), Şiir Mecmuâlarında XVI ve XVII. Asır Divan Şiiri

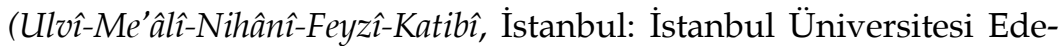
biyat Fakültesi Yay., Seri:1, Fasikül:3, 1-30.

Tarlan, Ali Nihad (1963), Necati Beg Divanı, İstanbul: Milli Eğitim Basımevi.

Tarlan, Ali Nihad (1968), Zâtî Divanı, İstanbul: İstanbul Üniversitesi Edebiyat Fakültesi Yay.

Tarlan, Ali Nihad (1992), Hayâlî Divamı, Ankara: Akçağ Yay.

Tarlan, Ali Nihad (1992), Ahmet Paşa Divanı, Ankara: Akçă̆ Yay.

Tekin, Gönül A. (2004), "Yakın Doğu Mitolojisinde Kartal ve Güneş”, Türklük Bilgisi Araştırmaları (Journal of Turkısh Studies) Günay Kut Armaganı, Published at the Department of Near Eastern Languages and Civilizations Harvard University, Volume: 28 / II, 85-111.

Tekin, Gönül A. (2006), "Anka ve Güneş", Türklük Bilgisi Araştırmaları (Journal of Turkısh Studies) Orhan Okay Armağanı, Published at the Department of Near Eastern Languages and Civilizations Harvard University, Volume: 30 / III, 209-236.

Timurtaş, Faruk Kadri (1980), Şeyhî ve Hüsrev ü Şîrî'i, İstanbul: İstanbul Üniversitesi Edebiyat Fakültesi Yay.

Tökel, Dursun Ali(2000), Divan Şiirinde Mitolojik Unsurlar, Ankara:Akçağ Yay.

Tulum, Mertol ve M. Ali Tanyeri (1977), Nev'i Divanı, İstanbul: İstanbul Üniversitesi Edebiyat Fakültesi Yay.

Üzgör, Tahir (1991), Fehîm-i Kadîm, Ankara: Dil ve Tarih Yüksek Kurumu Atatürk Kültür Merkezi Yayını.

Yeniterzi, Emine (1999), "Divan Şiirinde Ölüme Dair Bazı Hususlar", Selçuk Üniversitesi Sosyal Bilimler Dergisi, V, 115-139.

Zülfe, Ömer (2005), "Üsküf" Üzerine", Türk Kültürü İncelemeleri Dergisi, XII, 167-190. 